\title{
SESSENTA ANOS DE VERTICALIZAÇÃO EM LONDRINA/PR
}

\author{
SIXTY YEARS OF VERTICALIZATION IN LONDRINA/PR
}

SESENTA AÑOS DE VERTICALIZACIÓN EN LONDRINA/PR

\section{Tânia Maria Fresca}

Doutora em Geografia Humana pela Universidade de São Paulo (2000) e Pós-Doutorado na Universidade Federal do Rio de Janeiro (2011). Professora Associada do Departamento de Geociências da Universidade Estadual de Londrina (UEL). Professora permanente do Programa de Pós-Graduação em Geografia da Universidade Estadual de Maringá (UEM).

E.mail:tania_geografia@yahoo.com.br

\section{Edilson Luis de Oliveira}

Doutor em Geografia Humana pela Universidade de São Paulo. Pofessor adjunto do Departamento de Geociências da Universidade Estadual de Londrina(UEL).

Departamento de Geociências - UEL. Centro de Ciências Exatas, Departamento de Geociências. Campus Universitário s/n. Campus Universitário. 86051990 - Londrina, PR - Brasil - Caixa-postal: 6001 E.mail:edilson@uel.br

\section{Resumo}

A verticalização entendida como construção de edifícios de quatro pavimentos e mais, é um processo complexo que reúne diferentes tipos de capital e têm efeitos profundos na estrutura urbana das cidades em que ocorre. Em Londrina - PR a verticalização começou na década de 1950 e teve lugar de forma contínua ao longo das últimas seis décadas. O principal objetivo deste artigo é discutir relações entre a verticalização em Londrina e os modos de produzir e financiar a construção de edifícios verticais destinados à habitação, no contexto da urbanização brasileira. Um objetivo secundário é apontar alguns elementos da seletividade espacial intraurbana inerentes à produção de edifícios verticais que se manifestam nessa cidade. Para atingir estes objetivos, a periodização é usada como um instrumento analítico teórico e metodológico e as variáveis-chave consideradas são a área construída, o número de edifícios produzidos e as áreas da cidade em que se concentraram, durante os últimos 60 anos em Londrina.

Palavras-chave: Verticalização; Incorporadoras; Construtoras; Financeirização; Londrina - PR.

\section{Abstract}

The verticalization understood as buildings construction of four floors and more, is a complex process that brings together different types of capital and have deep effects in the urban structure of the cities where it occurs. In Londrina - PR, verticalization began in the 1950s and took place continuously over the past six decades. The main goal of article is to discuss relations between the verticalization in Londrina and ways to produce and finance the construction of vertical buildings for housing in the Brazilian urbanization context. A secondary objective is to show some elements of the spatial intra urban selectivity inherent in the production of vertical buildings that appear 
in this city. To achieve these objectives the periodization is used as a theoretical and methodological analytical instrument and the key variables considered are the built area, the number of buildings produced and the areas of city in which these buildings have concentrated, during the past 60 years in Londrina.

Keywords: Verticalization; Incorporators; Building Companies; Financialization; Londrina.

\section{Resumen}

La verticalización, entendida como la construcción de edificios con cuatro pisos y mas, es un proceso complejo que reúne diferentes tipos de capital y tiene efectos profundos en la estructura urbana de las ciudades donde ocurre. En Londrina, la verticalización comenzó en la década de 1950 y se llevó a cabo de forma continua durante los últimos seis decenios. El objetivo principal del artículo es discutir las relaciones entre la verticalización en Londrina y las maneras de producir y financiar la construcción de edificios verticales para la vivienda en el contexto de la urbanización brasileña. Un objetivo secundario es mostrar algunos elementos de la selectividad espacial intraurbana inherente a la producción de edificios verticales que aparecen en esta ciudad. Para lograr estos objetivos, la periodización es utilizada como un instrumento de análisis teórico y metodológico y las variables clave que se consideran son la superficie construida, el número de edificios producidos y las áreas de la ciudad en la que estos edificios se han concentrado durante los últimos 60 años en Londrina

Palavras clave: Verticalización; Incorporadores; Constructoras; Financiarización; Londrina. 


\section{INTRODUÇÃO}

A verticalização compreendida como processo de produção, reprodução e apropriação do espaço urbano por meio da construção de edifícios com quatro ou mais pavimentos, reúne e integra interesses de diversos tipos de capital e tem como uma de suas características geográficas marcantes, a seletividade espacial.

A verticalização não ocorre de forma aleatória no tecido urbano de uma cidade e em uma rede urbana regional. No Brasil, apesar de não se constituir como regra geral, a verticalização tem início nas áreas centrais das cidades e então se espraia para locais dotados de infraestrutura, equipamentos urbanos e alguma centralidade (SOUZA, 1994). Da mesma forma, não se verifica a transformação intensiva da paisagem urbana por meio da verticalização em todas as cidades de uma rede urbana. Existe por parte dos vários agentes que participam da verticalização, nítida preferência por cidades que exercem papéis de destaque na divisão territorial do trabalho. Tais cidades apresentam demandas de intensificação do uso do solo e de diversificação do meio construído, constituindo assim, mercados imobiliários dinâmicos e propícios à verticalização. Essas condições se apresentam com maior frequência nas regiões metropolitanas e espaços metropolizados (LENCIONI, 2003) como Londrina - PR.

A metropolização do espaço é entendida como processo que vai "[...] imprimir aos espaços urbanos, características da metrópole, porque muitas atividades, até então exclusivas da metrópole, necessitam ser reproduzidas fora dela para que a reprodução do capital em geral continue sua expansão (LENCIONI, 2004, p. 157). Em outros termos, a autora refere-se a magnitude dos investimentos de capital, ao desenvolvimento das atividades de serviços, especialmente relacionados a gestão e administração. Posto de outra forma, a autora fala de um conjunto de atividades econômicas no âmbito da funcionalidade de uma cidade, que representa a forma como a mesma se insere na divisão territorial do trabalho e as correlatas atividades de apoio às empresas. Além destas, Lencioni (2004) acrescenta a tendência a descentralização das atividades comerciais na forma de subcentros espontâneos e planejados (shopping centers) e a crescente expansão dos socialmente excluídos. Defendendo a ideia de que não é mais possível abordar o urbano como localidade mas, incorporando a noção de região nas análises urbanas, explicita que uma cidade com características metropolitanas são aquelas que apresentam “[...] infraestrutura de serviços bastante desenvolvidas, presença significativa de atividades baseadas em trabalho imaterial, vinculado frequentemente com as chamadas cidades globais, praça financeira expressiva, tecido urbano que contem várias centralidades" (LENCIONI, 2004, p. 164). 
Isto significa que um espaço metropolitano na perspectiva aqui adotada, não significa ser metrópole, mas apresentar inúmeras características similares às metropolitanas. Tão pouco significa ser cidade média, porque há muito ultrapassou os elementos constitutivos deste conceito. Trata-se de um escalão urbano em que definições são perigosas, mas há que se reconhecer a enorme complexidade de seu espaço e atividades urbanas.

E no caso de Londrina, elas são várias conforme já demonstradas por Fresca (2012, 2013, 2014). A começar pelo fato da mesma ser a principal cidade de uma aglomeração urbana que envolve em 2015, mais de 1 milhão de habitantes; cujas cidades da mesma apresentam fortes articulações materiais e imateriais de interdependência funcional; uma dessas últimas, apoia-se nos importantes deslocamentos pendulares que se realizam entre as mesmas, atingindo para muitas delas, percentual de quase $10 \%$ da população economicamente ativa; no fato de Londrina colocar-se como a cidade que atende inúmeras demandas de serviços de apoio à empresas, na forma de consultorias jurídicas, auditorias diversas (com filiais em Curitiba, Porto Alegre e Maringá); serviços de comunicação e propaganda (com mais de 100 empresas do segmento tendo como clientes, várias empresas de atuação nacional e internacional); presença de geradoras de TV aberta com horas de programação regional ( SBT, CNT, Bandeirantes e Record); de oferta de serviços públicos federais para empresas e famílias; de centros de pesquisas diversas, mas com destaque para aquelas vinculadas aos agronegócios, como a Embrapa-soja e o Iapar, ambos sediados em Londrina; um dos sete laboratórios existentes no Brasil para ensaios têxteis denominado Lalon; cerca de 34 mil alunos de graduação e mais 5 mil alunos de pós-graduação; de sistema de comunicação e informação através telefonia fixa, móvel e fibra óptica, de elevada densidade (SANTOS, 2014); de infraestrutura qualitativa na forma de transporte rodoviário, ferroviário e aéreo ( $23^{\circ}$ aeroporto em movimento de passageiros em 2014), dentre outras. Em relação a questão da presença de sistema bancário, notar que esta cidade coloca-se como a segunda mais importante do estado conforme pode ser verificado nos trabalho de Dias (2011); além deste, ressalte-se o fato da cidade contar com regional do Banco do Brasil, superintendência da Caixa Econômica Federal e de gerência regional do Bradesco, cujas áreas de atuação das mesmas se realizam em vasta parcela do norte do estado.

A presença destes elementos não é exclusividade de Londrina, nem se vinculam ao denominado processo de reestruturação urbana como afirmam determinados autores. $\mathrm{O}$ fato é que, estes elementos há muito se fazem presentes e vem sendo expandidos desde os anos de 1970, em elevada densidade de suas presenças. Da mesma forma, a dinâmica intraurbana da cidade é marcada pela presença de 5 shopping-center, mais um em fase final, bem como vários subcentros espontâneos na forma de ruas comerciais. Nos limites 
deste artigo, os aspectos ressaltados anteriormente são referências para que se explicite o que se entende pelo fato da cidade de Londrina ser considerada como um espaço com características metropolitanas. A verticalização pode ser entendida a partir de sua relação simbólica, não exclusivamente, com a metropolização, dada pela densidade que a mesma apresenta na cidade em tela.

Com relação a seletividade espacial intraurbana, no entanto, entende-se que esta não deve ser tomada como uma constatação. Ela é, antes de tudo, aquilo que deve ser explicado. Segundo Milton Santos (2004, p.86) “[...] os eventos, as ações não se geografizam indiferentemente". O lugar, nesse caso a cidade de Londrina, e o evento - a verticalização - se encontram e se redefinem mutuamente. A realização de dada ação em dado lugar requer uma teoria capaz de lidar simultaneamente com a especificidade dos lugares e com as leis gerais que movem a ação e os agentes. Neste caso, as incorporadoras e construtoras que reúnem os capitais e as técnicas necessárias à produção de edifícios verticais como mercadorias e as condições dadas pelas políticas habitacionais e pela normatização relativa à produção e financiamento de edifícios residenciais. Um dos elementos teóricos fundamentais para elucidação da verticalização como processo, que altera quantitativa e qualitativamente as dimensões do meio construído de uma cidade, é justamente sua periodização. Por meio da periodização é possível tornar clara e objetiva a determinação do espaço como fator (SANTOS, 2004) e fazer apontamentos sobre seletividade espacial intraurbana e suas ligações com as metamorfoses dos capitais implicados na verticalização.

Iniciada nos anos 1950, a verticalização de Londrina atravessou várias décadas sem sofrer interrupções. Entre os anos 1950 e 1970, formaram-se grandes incorporadas de capital local, que se destacaram na produção de edifícios na cidade. A partir dos anos 1980 e até 2000, algumas dessas empresas de origem local, lograram estabelecer bases para atuar no mercado nacional e latinoamericano. Nesse início de século XXI, um novo ambiente de negócios e a intensificação da financeirização das várias etapas de produção e comercialização de edifícios, levaram incorporadoras nacionais a se internacionalizarem. A abertura de capital, por meio da oferta pública de ações (OPA) e a aquisição de parte dessas empresas por Fundos Equity, levou a produção de edifícios altos a outro nível de articulação com as tendências gerais do processo de globalização, particularmente a dominância do capital fictício sobre o produtivo. A financeirização global está presente na verticalização em Londrina e é característica importante do terceiro período deste processo.

Para discutir a verticalização em Londrina e algumas de suas relações com os modos de produzir e financiar a construção de edifícios verticais destinados à habitação, no contexto da urbanização brasileira e fazer alguns apontamentos sobre a seletividade espacial 
intraurbana inerente à produção de edifícios verticais e suas manifestações nessa cidade, divide-se o presente artigo em cinco partes, além desta introdução. Na primeira parte, cujo aspecto metodológico é o mais destacado, discute-se a periodização da verticalização em Londrina e identificam-se as variáveis fundamentais do processo. Em seguida, nas partes dois, três e quatro descreve-se e analisa-se a verticalização londrinense à luz dos desdobramentos ocorridos considerando as variáveis adotadas; identificam-se os principais agentes desse processo e a geografia de suas ações na cidade entre os anos 1950 e 2013. Por fim, apresentam-se as considerações finais, buscando elucidar aspectos do período atual, marcado pela financeirização das incorporadoras e pela intensificação da concorrência entre grandes empresas na produção edifícios verticais em Londrina.

\section{A VERTICALIZAÇÃO EM LONDRINA: PERIODIZAÇÃO E ANÁLISE}

O processo de verticalização é uma característica marcante da paisagem de lugares onde o processo de modernização se instala com intensidade. Em Londrina, cidade jovem com pouco mais de 80 anos de existência, a precocidade do processo de verticalização e sua articulação econômica e simbólica com a modernização está bem caracterizada pelos estudos de Prandini (2007 [1954]), Linardi (1995), Fresca (2005), Passos (2007) e Casaril (2008). O mapa 1 apresenta a localização de Londrina no Paraná, seu perímetro urbano atual e serve de referência espacial para situar os outros mapas que representam a dinâmica espacial da verticalização e da seletividade espacial intraurbana.

Mapa 1: Londrina: área urbana, bairros e localização no Paraná
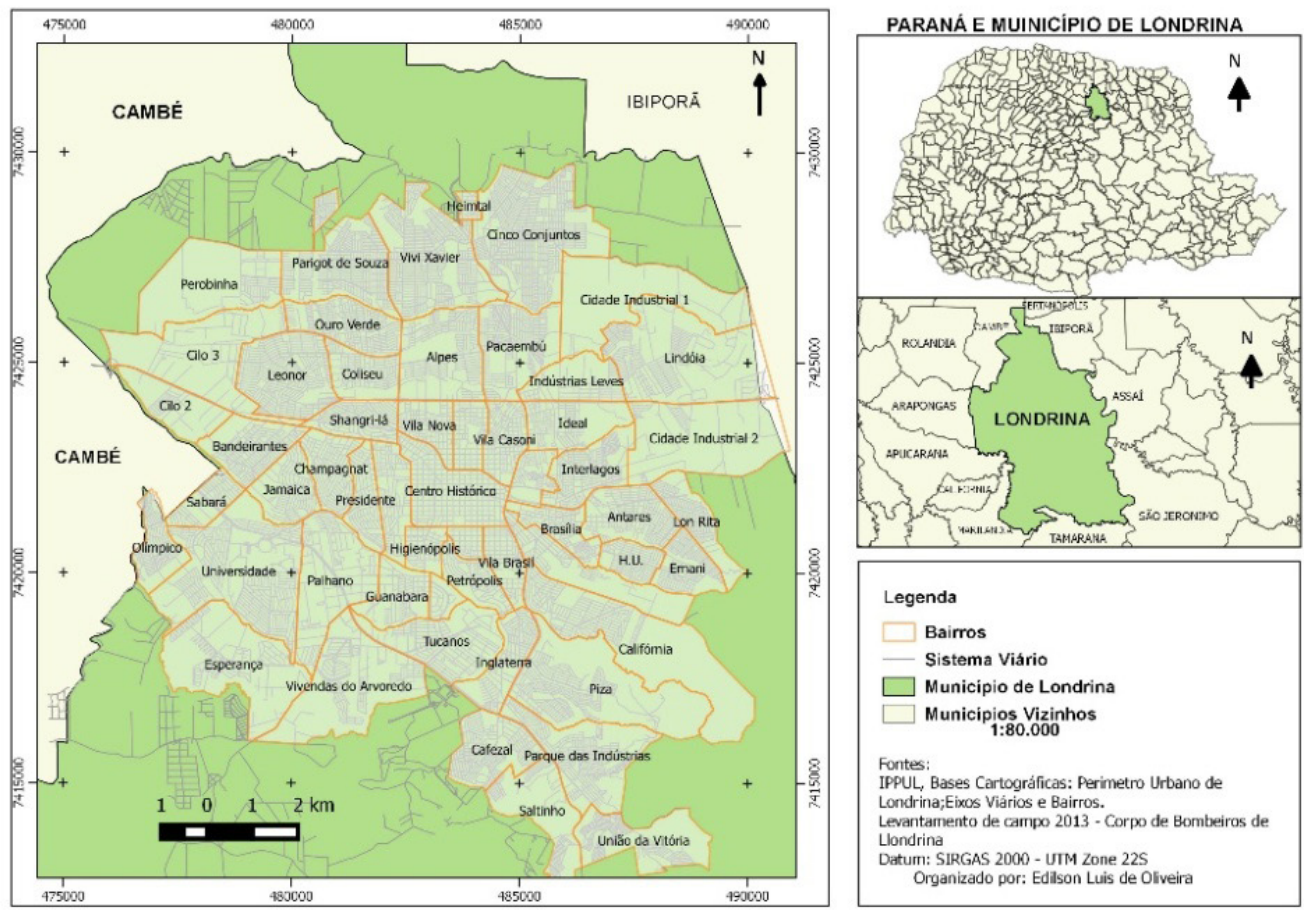

a 
A verticalização londrinense acompanhou a concentração da riqueza gerada pelo complexo agrário cafeeiro (PADIS,1984) nos chamados "anos dourados". O complexo agrário cafeeiro, abarca além da produção e exportação de café, a produção de insumos para cafeicultura, alimentação os trabalhadores e cereais nas lavouras intercalares. Inclui ainda a intrincada comercialização do café e de outros gêneros agrícolas, transporte, financiamentos à produção e operações comerciais, entre outras. No Norte do Paraná esse conjunto de atividades relativas ao complexo agrário cafeeiro esteve muito presente ao longo do primeiro período da verticalização londrinense, bem como a situação geográfica da cidade no contexto regional, contribuiu na constituição de centralidades sobre as quais erigiu forte poder de polarização regional apoiado em uma gama diversificada e numerosa de serviços e no comércio varejista e atacadista.

Os gráficos 1, 2 e 3, apresentam a evolução da verticalização em Londrina sob a perspectiva de duas varáveis de análise: a área total construída e o número de edifícios.

Gráfico 1: Londrina, área construída de edifícios verticais por década: 1950-2013

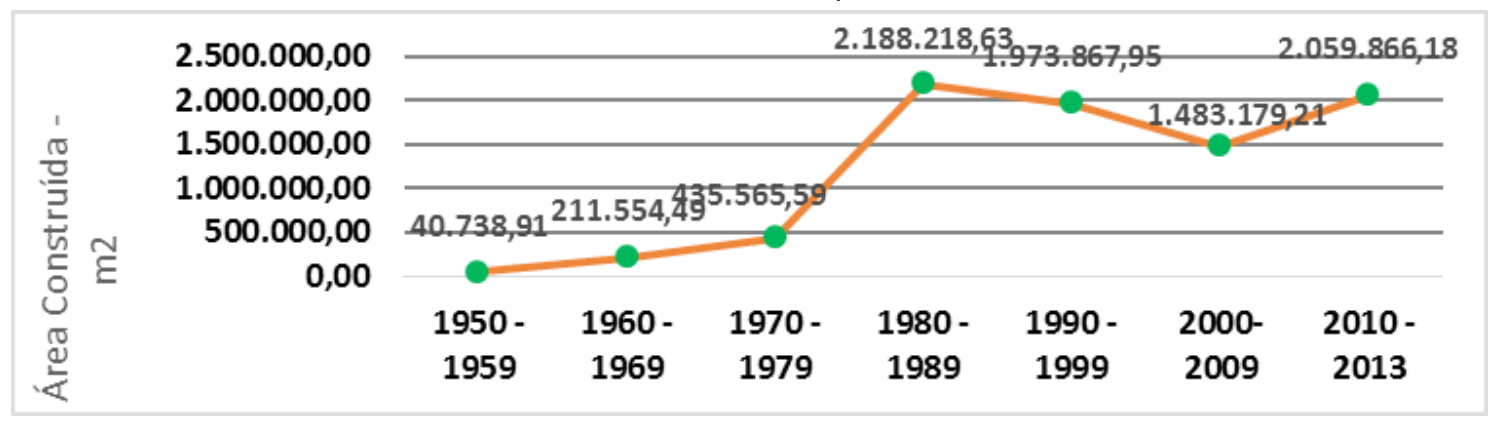

Fontes: Casaril (2008), Passos (2007) e Corpo de Bombeiros de Londrina 2013.

Gráfico 2: Londrina, número de edifícios por década: 1950-2013

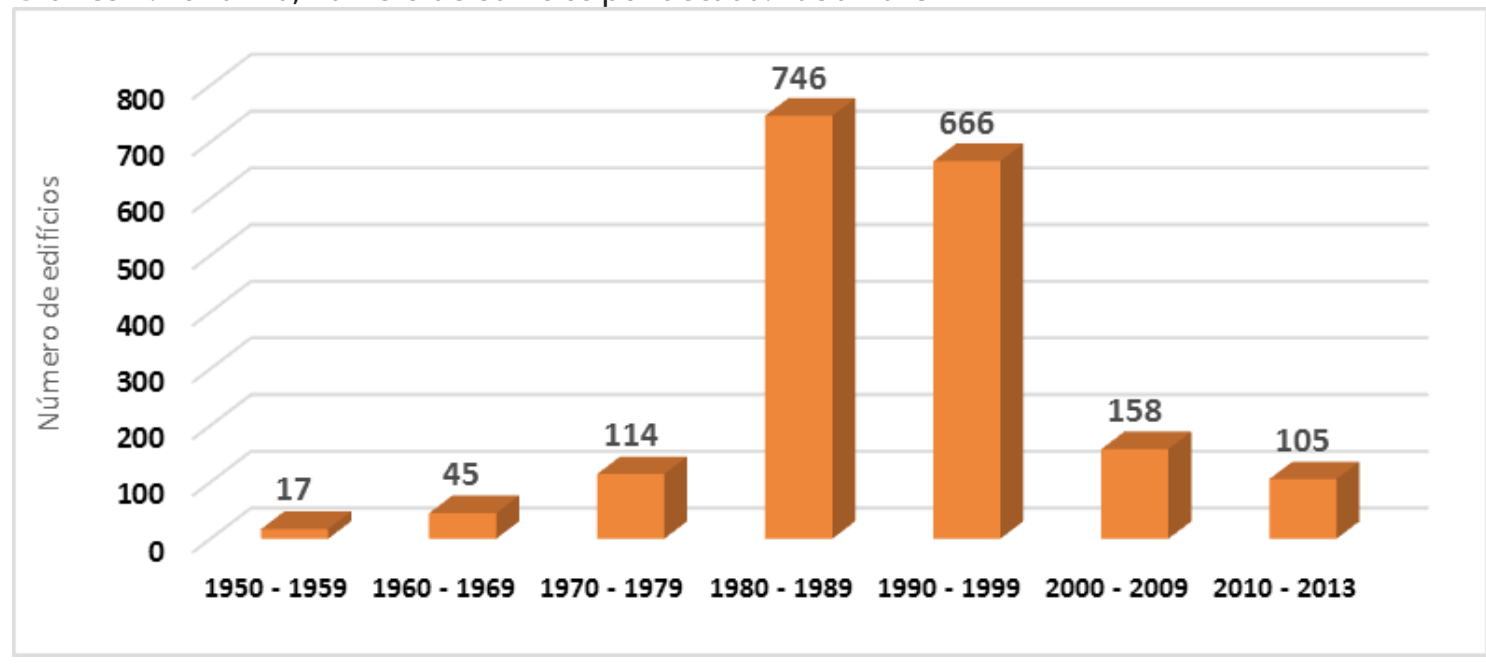

Fontes: Casaril (2008), Passos (2007) e Corpo de Bombeiros de Londrina 2013. 
Gráfico 3: Londrina, número médio de edifícios por ano: 1950-2013

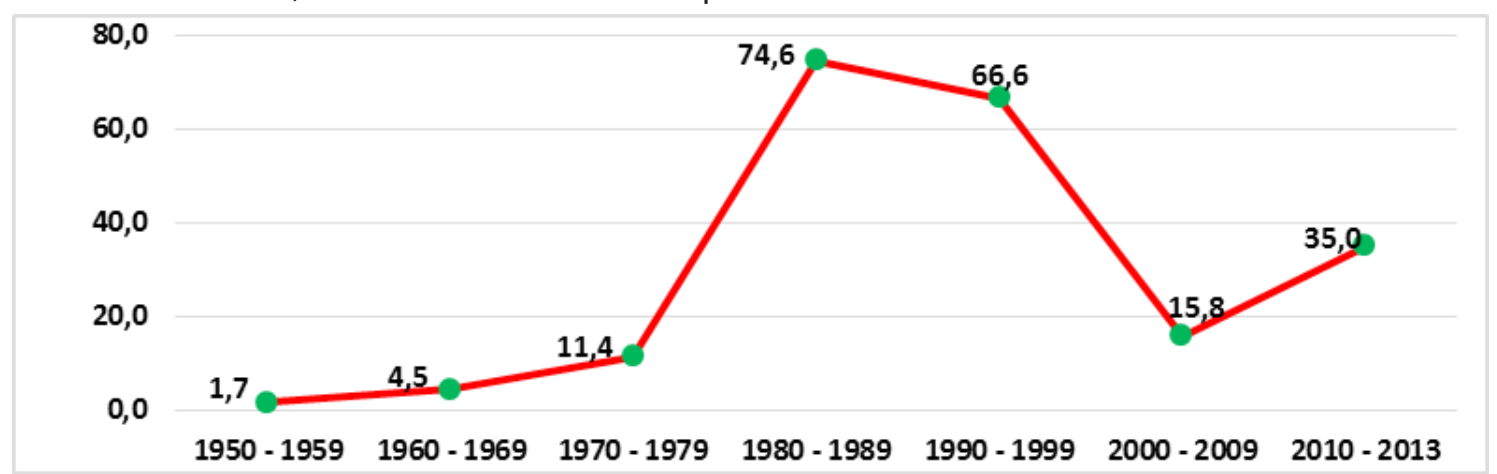

Fontes: Casaril (2008), Passos (2007) e Corpo de Bombeiros de Londrina 2013.

A periodização de um processo em estudos geográficos tem papel importante, uma vez que permite colocar em destaque a dimensão temporal como elemento de análise da dinâmica espacial de um dado lugar. A definição de períodos resulta da identificação de variáveis de um evento que tem sua duração e significado demarcados a partir da contextualização das inter-relações entre processos, formas, normas e funções (SANTOS, 1992).

\begin{abstract}
A integração entre variáveis, eventos, processos, funções e formas estabelece diversos graus de coerência e coesão que auxiliam na definição da periodização. A cada novo período, a coerência e a coesão anteriores podem se desmanchar (SILVEIRA, 2004). Por outro lado, a situação atual depende de influencias e condições herdadas dos períodos precedentes (OLIVEIRA, 2011, p.15).
\end{abstract}

Desta forma, em termos metodológicos, torna-se pertinente em uma situação dada, realçar tanto a duração como as transformações nas relações entre objetos geográficos e ações que se realizam em um dado lugar e definir as variáveis explicativas que permitem elucidar essas relações. Foram selecionadas como variáveis básicas para acompanhar a verticalização em Londrina os dados relativos a área construída e ao número de edifícios, priorizando-se na definição dos períodos, o primeiro conjunto de dados.

Com base nos dados representados nos gráficos 1, 2 e 3, e complementando a análise com informações sobre os agentes produtores e as normas definidoras do financiamento imobiliário, fica evidente a existência de três momentos distintos no processo de verticalização em Londrina. Um período inicial e de consolidação da verticalização entre 1950 e 1979. O segundo período, entre 1980 e 1999, em que ocorre forte aceleração do processo, ainda que com variações internas, isto é, fases de declínio e retomada, mas que definitivamente estabelecem outro patamar para a produção de edifícios altos na cidade. Por fim, o terceiro período a partir do início do século XXI em que, um novo marco regulatório autoriza novas possibilidades de ação e enseja uma retomada do dinamismo 
do mercado imobiliário, atrelando-o à processos globais de hegemonização do capital financeiro sobre o capital produtivo, ensejando novas condições de concorrência entre agentes produtores, com reflexos sobre suas estratégias de competição. Esse terceiro período, de financeirização da verticalização, terá consequências diretas sobre as características gerais dos empreendimentos.

Gráfico 4: Londrina, periodização da verticalização.

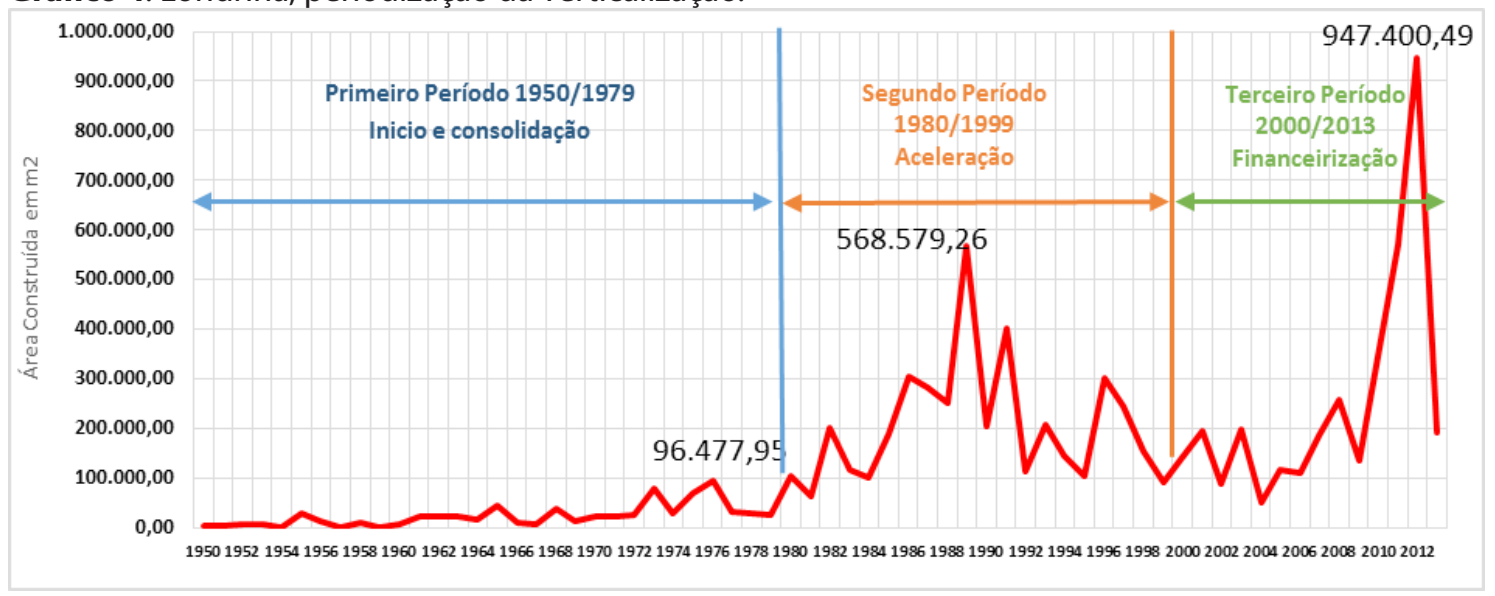

Obs.: Os números no interior do gráfico indicam picos de área construída por ano, em cada período: 1977 - 96,47 mil m²; $1989-568,57$ mil m² e $2012-947,4$ mil m$^{2}$

Fontes: Casaril (2008), Passos (2007) e Corpo de Bombeiros de Londrina, 2014.

No que tange as implicações da verticalização na estrutura urbana de Londrina, a sucessão dos períodos revela uma paulatina ampliação das áreas da cidade diretamente envolvidas no processo de verticalização a partir do centro histórico. Uma dessas áreas configuradas a partir dos anos 1990 e caracterizada por um grau elevado de concentração de edifícios verticais à semelhança do centro histórico é a Gleba Palhano, localizada no quadrante sudoeste de Londrina.

\section{OPRIMEIRO PERÍODODAVERTICALIZAÇÃOEM LONDRINA:INÍCIOECONSOLIDAÇÃODO PROCESSO}

Os anos 1950 são para Londrina uma fase de grande dinamismo econômico e demográfico determinada pelo auge do chamado complexo agrário cafeeiro. No início dos anos 1950 a cidade fundada há pouco mais de 20 anos possui um total de 66.851 habitantes e precisamente 50\% deles residem no distrito sede do município (IBGE, 1950).

O papel de comando regional exercido por Londrina foi paulatinamente reforçado pela ampliação de seu setor de serviços, particularmente aqueles relativos à gestão dos fluxos articulados à produção agrícola, mas também os serviços que visavam o atendimento da população. Como resultado, o meio construído de Londrina diversificou-se e tornou-se 
mais complexo na medida em que, intensificava-se a divisão social e territorial do trabalho no município e em seu entorno regional (OLIVEIRA, 2011, p.61). Capitais acumulados na circulação do café, especialmente pelos chamados maquinistas, intermediários que compravam café dos produtores, classificavam, beneficiavam e revendiam às casas importadoras ou outros grandes atacadistas, foram aplicados na construção de edifícios, como o Edifício Sahão de nove andares, edificado em 1952 (ZUCKER, 1989, p.40).

Nesse contexto, a verticalização em Londrina bem como a definição dos contornos do setor de construção civil em moldes industriais, dá seus primeiros passos. A modernização, característica intrínseca da dinâmica de transformação da paisagem londrinense (LINARDI, 1995), manifesta-se por meio da construção de edifícios em sistema de condomínio mediante a incorporação imobiliária. A incorporação imobiliária, inovação que já se desenvolvia em São Paulo desde os anos 1930, autorizada pela chamada Lei dos Condomínios de 1928 (BRASIL, 1928), chega com velocidade em Londrina.

A crise internacional que provocou transformações na cafeicultura após 1929, a intensificação da urbanização na escala nacional, as mudanças políticas no Brasil após a revolução de 1930 com o Estado Novo, são elementos da conjuntura na qual se deu a promulgação da Lei do Inquilinato de 1942 (BRASIL, 1942), que congelou aluguéis e inibiu seus futuros reajustes. A Lei do Inquilinato alterou profundamente a dinâmica do mercado imobiliário no país e favoreceu a construção voltada para produção de edificações como mercadorias e não mais para renda por meio de aluguéis.

Em São Paulo e Rio de Janeiro ao longo dos anos 1950, o setor da construção civil responde às novas oportunidades abertas pelo novo marco regulatório, com a construção de edifícios altos nas áreas centrais atendendo a demanda por habitação das novas classes médias urbanas em formação no contexto da chamada "Era Vargas". Além disso, não se deve ignorar o aspecto simbólico envolvido na nova forma espacial: o edifício alto para fins residenciais.

O habitar em unidades de edifícios altos foi associado a um viver metropolitano, mais moderno. O progresso da cidade, a vida metropolitana, a modernidade dos edifícios, a atualidade de sua habitação, enfim, eram relacionadas e incorporadas às características dos produtos que eram vendidos. Para a incorporação imobiliária, a metrópole se transformou em um produto vendável (ANITELLI; TRAMONTANO, 2012, p.75).

Baseado em Linardi (1995, p.229), entende-se que a construção de edifícios altos em Londrina esteve desde o início, vinculada ao pioneirismo e a modernidade que facilitaram a aceitação de inovações e a influência externa, especialmente a paulistana. Portanto, no caso londrinense, não se tratava apenas de densificar o uso do solo na área central ou de 
uma nova atividade geradora de lucro. Aliava-se a esses objetivos, a vontade de manifestar na paisagem urbana, a empiricização da vitória daqueles que conseguiram se tornar elite na formação socioespacial regional (FRESCA; OLIVEIRA, 2005, p.127).

Ao longo dos anos 1950, foram construídos na área central da cidade, 17 edifícios com mais de quatro pavimentos. Destes, oito edifícios para uso comercial, seis para uso misto (comercial e residencial) e apenas três exclusivamente residenciais (CASARIL, 2008, p.97). Ainda que o número de edifícios para uso residencial seja pequeno, sua existência já sinalizava tendência que se firmaria nas décadas seguintes: produzir grande número de unidades habitacionais em edifícios altos.

Do ponto de vista dos agentes produtores diretamente envolvidos na construção dessas novas e marcantes formas espaciais, que redefinem a paisagem urbana de Londrina e lhe conferem um ar de modernidade, destacam-se construtoras de capital local e de base familiar. Uma das mais importantes foi a Construtora e Incorporadora Veronesi, fundada por uma família italiana de mesmo nome que migrou para Londrina nos anos 1950, rapidamente passando do estágio de construtora para tornar-se construtora e incorporadora (CASARIL, 2008, p.104). Essa empresa foi responsável pela construção de edifícios como o Centro Comercial o mais alto dos anos 1950 com 22 pavimentos e o edifício Bosque, que abriga o jornal Folha de Londrina. Também merece destaque a Construtora Brasília, empresa familiar e de capital local, que nas décadas seguintes se constituiria como uma das mais ativas na construção civil londrinense, sendo responsável pela construção de mais de 50 prédios (PASSOS, 2007, p.72). Outras construtoras como a Incorporadora Alvorada, Construtora Predial e Construtora Bresslau e Bastian completam o quadro dos agentes produtores da verticalização em Londrina nos anos 1950.

Nos anos 1960 a verticalização londrinense se intensifica e acompanha a dinâmica do processo de urbanização na região Norte do Paraná. A população urbana de Londrina salta de 57\% para 78\% entre 1960 e 1970 respectivamente. Simultaneamente a população total do município mais do que dobra, passando de 132.821 habitantes em 1960 para 288.532 em 1970 (IBGE, 1960; 1970). O número de edifícios construídos salta de 17 para 45, destacando-se os edifícios com mais de nove pavimentos que somam 21 edifícios, $47 \%$ do total. A área construída quintuplica passando de 40 para $211 \mathrm{mil} \mathrm{m}^{2}$ e o número de construtoras atuantes e formadas localmente também se amplia (CASARIL, 2008, p.120).

Vale destacar que nos anos 1960 o uso exclusivamente residencial supera o comercial e o misto (comercial e residencial). Firma-se nesse período, o uso residencial como predominante na verticalização londrinense, acompanhando assim a tendência nacional 
de estabelecer o apartamento como uma das possibilidades de habitar a cidade. Assim como nos anos 1950, os edifícios verticais permaneciam concentrados no centro principal de Londrina (CASARIL, 2088, p.132-133). Essa localização acompanhava a presença de infraestruturas como redes de saneamento básico, eletricidade, telefonia e meios de transporte. Contava também com a proximidade de serviços públicos e privados, garantindo total acessibilidade a esses requisitos fundamentais do modo de vida urbano.

Os anos 1960 são marcantes para definição das características fundamentais do processo de verticalização em Londrina, mas além das transformações locais ocorreram transformações fundamentais nos marcos regulatórios da construção civil e especialmente da verticalização no âmbito nacional.

Uma das novidades foi a promulgação da Lei da Incorporação Imobiliária (BRASIL, 1964), que regulamentou as formas de organizar a divisão da propriedade e as responsabilidades na constituição de condomínios abrigados em edifícios de vários andares. Porém, a mais importante transformação implantada pela Ditadura Militar, foi a constituição do Sistema Financeiro da Habitação (SFH), do Banco Nacional da Habitação (BNH) e do Sistema Brasileiro de Poupança e Empréstimo (SBPE). Com as novas normas e instituições, o Estado canalizou vultosos recursos para enfrentar um problema crônico da indústria da construção, o financiamento. No âmbito do SBPE, por exemplo, criou o plano empresário que visava especificamente o financiamento de obras propostas por incorporadores.

A fim de garantir fontes estáveis e permanentes de financiamento, criou-se o Sistema Financeiro da Habitação (SFH), que utilizou poupança tanto compulsória (FGTS) quanto voluntária (caderneta de poupança/letra de câmbio). Da mesma forma, para evitar a descapitalização do Banco, como ocorreu com seus predecessores (Fundação da Casa Popular e Carteiras Imobiliárias dos Institutos de Pensão e Aposentadorias), instituiu-se uma "moeda forte" imobiliária (unidade-padrão de capital, UPC) e institucionalizou-se a correção monetária das prestações e dos saldos devedores dos mutuários finais (RANGEL, 1986a, p.45-46)

A nova política materializou-se através da implantação de uma completa rede de agências públicas e privadas que funcionava sob a égide do BNH (DE AZEVEDO, 1988). O mercado imobiliário foi estratificado segundo níveis de renda dos mutuários (popular, econômico e médio), cada qual sob a responsabilidade de um agente promotor e com legislação específica (DE AZEVEDO, 1988, p.110).

A convergência efetiva entre as novas condições institucionais e a aceleração da verticalização em Londrina, ocorreu a partir de meados dos anos 1960 e principalmente ao longo dos anos 1970. O gráfico 5 permite argumentar que, a partir do novo marco 
regulatório e principalmente em função das novas condições de financiamento da produção na construção civil, se estabeleceu um novo patamar para a verticalização no Brasil e para Londrina. Incide nesse mesmo período a intensificação da substituição da cafeicultura pelas culturas temporárias e mecanizadas de soja e trigo, aliadas a implantação de agroindústrias e cooperativas. As mudanças na divisão do trabalho fortalecem ainda mais a economia urbana de Londrina com novos elementos do circuito superior (OLIVEIRA, 2011).

Gráfico 5: Londrina, área construída dos edifícios verticais: 1950-1979

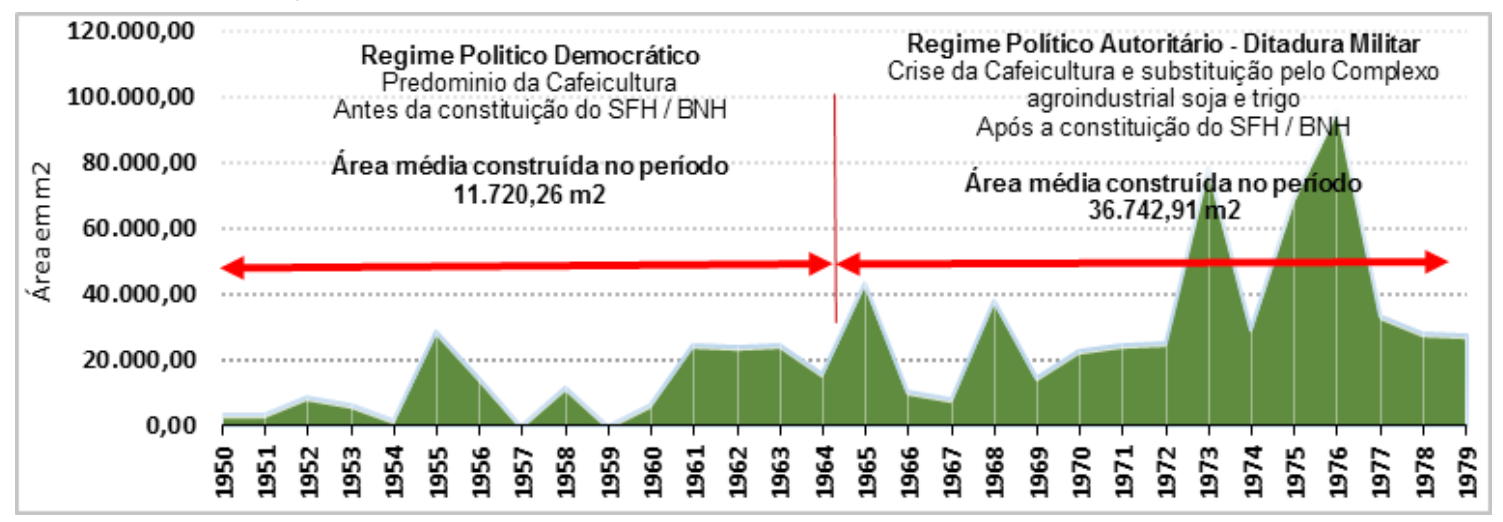

Fontes: Casaril (2008), Passos (2007) e Corpo de Bombeiros de Londrina 2013.

A divisão social do espaço também se altera. A segregação residencial e a expansão físico- territorial em Londrina se intensificam, tornando o meio construído ainda mais diversificado, fragmentado e complexo. Começam a ser construídos edifícios em áreas adjacentes ao centro principal, conforme mapa 2.

Embora ainda exista uma forte concentração dos edifícios verticais na área central, a partir dos anos 1970 sua localização paulatinamente começa a se alterar em relação às décadas anteriores. A expansão das redes de saneamento, eletricidade, telefonia e outras melhorias, ampliam as áreas passíveis de verticalização em Londrina. Alguns edifícios são construídos em bairros dotados de infraestrutura e adjacentes ao centro histórico nos quadrantes norte, noroeste, sul e sudoeste. Contudo, é ao sul do centro histórico que a verticalização se dará com mais intensidade. Em Londrina, do ponto de vista da segregação residencial, tornou-se marcante a distinção entre a porção norte e a porção sul da cidade, divididas pela linha férrea (ALVES, 1991; NAKAGAWARA, 1972; NANTES, 2003). Desta forma, a presença da verticalização residencial em bairros dos quadrantes sul e sudoeste acompanhou tendência de segregação estabelecida no início da construção da cidade. Seguiu também o percurso da valorização do solo criado, na medida em que as incorporadoras adensam o centro histórico e capturam a melhor acessibilidade presente naquela parte da cidade. 
Mapa 2: Verticalização em Londrina: primeiro período - 1950 a 1979

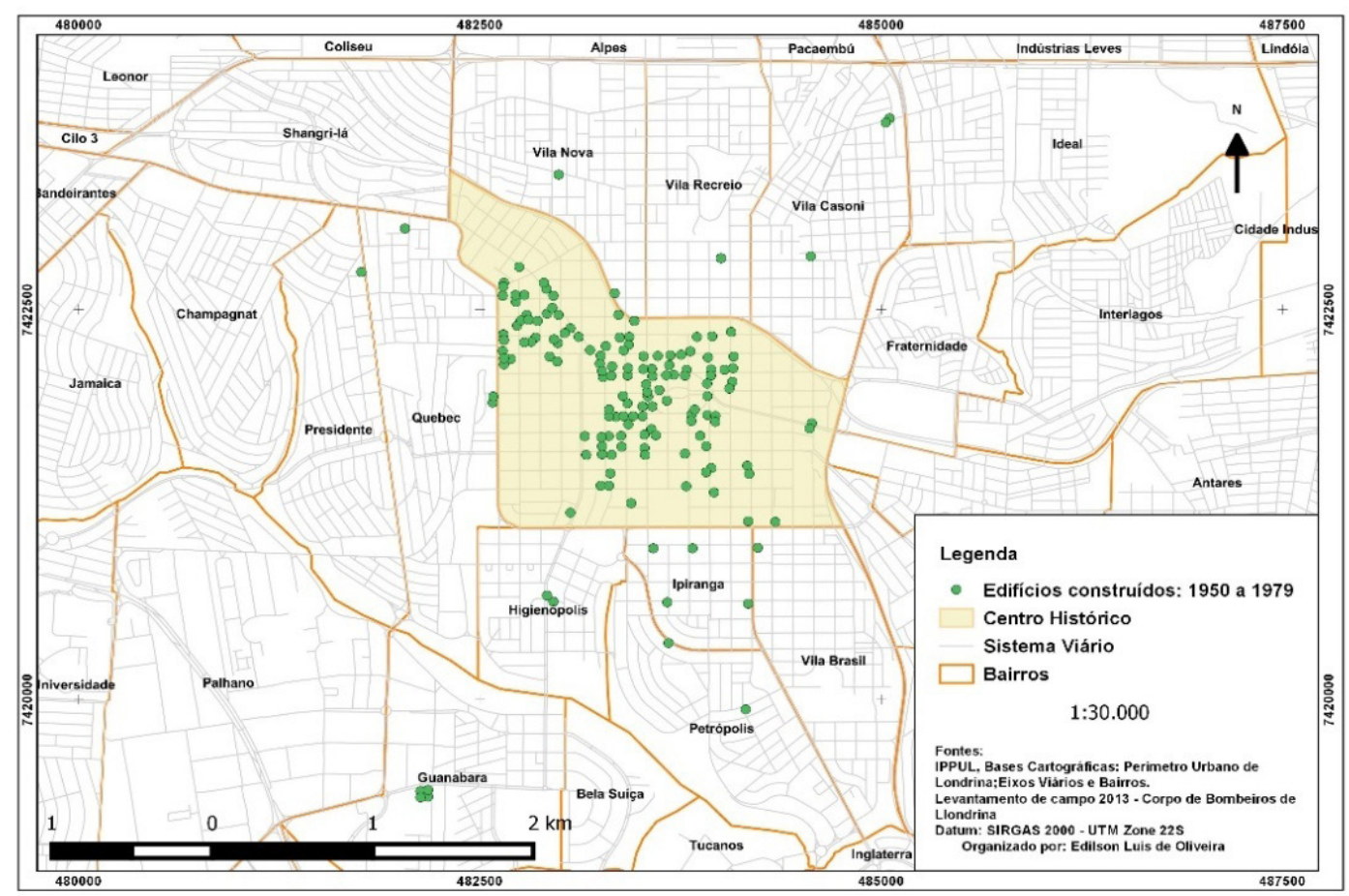

A verticalização se acelera em Londrina na última etapa desse primeiro período. A área construída dobra de tamanho, passando do patamar de $211 \mathrm{mil} \mathrm{m}^{2}$ nos anos 1960 para 435 mil m² nos anos 1970. O número de edifícios cresce duas vezes e meia, passando de 45 para 114 e mais de $40 \%$ desse total tem mais do que nove pavimentos (CASARIL, 2008, p.139). A exemplo de outros espaços metropolizados, Londrina expandia-se horizontal e verticalmente com muita rapidez. No caso da verticalização, a energia subjacente a essa transformação foram os recursos cativos do Fundo de Garantia por Tempo de Serviço (FGTS) e os da poupança reunidos no SFH e canalizados para habitação sob a coordenação do BNH. Tal situação propiciou a produção de edifícios altos para uso residencial de segmentos da classe média e investidores que, seguindo a tradição patrimonialista nacional, lastreavam parte de seus recursos em imóveis.

O novo ambiente de negócios criado a partir de meados dos anos 1960 e determinado pelas normatizações do SFH incidiu sobre a ampliação e regulação da demanda habitacional, trazendo novas condições concretas para a realização do apartamento como mercadoria, ao estabelecer condições favoráveis para financiamentos de longo prazo. Dentre essas condições destacou-se a correção monetária, inovação que viria para ficar, uma vez que permitia o ajuste dos financiamentos às condições macroeconômicas no longo prazo, particularmente a inflação (RANGEL, 1986b).

a 
No entanto, a baixa eficiência das políticas sociais autoritárias, como a aparente prioridade das faixas salariais mais baixas no SFH e o atrelamento das prestações dos mutuários aos reajustes salariais em termos de valores e de periodicidade, foram obrigando o sistema a criar mecanismos de ressarcimento para Bancos e outros agentes financiadores. Os saldos porventura existentes ao término dos contratos de financiamento para aquisição da casa própria seriam cobertos pelo Fundo de Compensação das Variações Salariais (FCVS). Os efeitos concretos dessa normatização, em termos da dinâmica do processo de verticalização londrinense, foram o incremento do número de edifícios e da área construída em meados dos anos 1970 e sua brusca redução nos anos de 1978 e 1979 em função da crise macroeconômica gerada pelo endividamento externo, pelo segundo choque do petróleo, entre outros eventos conjunturais. Outro efeito concreto foi a consolidação de construtoras e a multiplicação de edifícios construídos no sistema condomínio fechado ou preço de custo.

Nos anos 1970, ganhou força a incorporação e a formação de condomínios fechados, tendo como suporte técnico o chamado engenheiro responsável e como suporte financeiro um grupo de adquirentes, que eram simultaneamente financiadores da obra. Embora essa forma de proceder a incorporação de edifícios já estivesse presente na cidade desde os anos 1950, a ampliação da verticalização colocou essa estratégia de produção em um novo patamar. Nesse contexto, as construtoras contratadas são meras executoras da obra e o processo de incorporação, algumas vezes denominado a "preço de custo", ficava a cargo de uma espécie de cooperativa formada por adquirentes, engenheiro responsável e eventualmente um escritório de engenharia e/ou arquitetura que geralmente atuavam na parte técnica do projeto, acompanhamento da obra e, eventualmente na arregimentação de mão de obra via empreitada.

Na década de 1970 o sistema preço de custo tendo um engenheiro responsável pela obra, foi responsável pela construção de 17 dos 101 edifícios produzidos no período, ou seja, 16,8\% do total. Em termos de área construída o sistema de preço de custo respondeu por 74,2 mil m², o equivalente a $17 \%$ do total edificado nos anos 1970 . As principais construtoras atuantes em Londrina nos anos 1970 são apresentadas no quadro 1 . As 16 empresas listadas no quadro responderam por pelo menos um ponto percentual em relação ao total da área construída no período e indicam a diversidade e quantidade de agentes diretamente implicados no processo de verticalização em Londrina. De um modo geral, essas empresas eram de base familiar e seu capital de origem local. 
Quadro 1: Principais incorporadoras e/ou construtoras atuantes em Londrina: 1970-1979

\begin{tabular}{|c|c|c|}
\hline INCORPORADORASICONSTRUTORAS & $\begin{array}{c}\text { ÁREA } \\
\text { CONSTRUÍDA (m2) }\end{array}$ & $\begin{array}{c}\text { AREA } \\
\text { CONSTRUÍDA (\%) }\end{array}$ \\
\hline Brasília Ltda. & $109.683,41$ & 25,2 \\
\hline Cebel S/A & $60.258,10$ & 13,8 \\
\hline Plaenge S.A & $37.833,65$ & 8,7 \\
\hline Enoch Vieira dos Santos & $18.392,96$ & 4,2 \\
\hline Artenge /Simamura Daiwa & $16.958,47$ & 3,9 \\
\hline Teto - Engenharia Civil e Ltda. & $11.445,74$ & 2,6 \\
\hline Brastec-Eng. e Construções Ltda & $11.102,60$ & 2,5 \\
\hline Piaui - Construções Civis & $7.968,69$ & 1,8 \\
\hline Fevisa & $7.317,98$ & 1,7 \\
\hline Vezozzo Ltda & $6.957,13$ & 1,6 \\
\hline Palumbre Empreendimentos Imobiliários & $6.440,00$ & 1,5 \\
\hline Moreira Ltda & $6.105,73$ & 1,4 \\
\hline Jabur Ltda. & $5.546,25$ & 1,3 \\
\hline Paleari & $5.189,31$ & 1,2 \\
\hline Sato Engenharia Civil & $4.862,95$ & 1,1 \\
\hline Técnica Canadá Ltda & $4.402,12$ & 1,0 \\
\hline Total Parcial & $302.465,09$ & 73,5 \\
\hline TOTAIS GERAL 1970/79* & $435.565,59$ & 100,0 \\
\hline
\end{tabular}

*: O Total Geral representa a soma dos dados de todas as construtoras atuantes no período

Fontes: Casaril (2008), Passos (2007) e Corpo de Bombeiros de Londrina, 2013.

A divisão do trabalho estabelecida no processo de incorporação e as mudanças no ambiente de negócios favoreceram, paulatinamente, a consolidação de construtoras que assumiram o processo de incorporação. Em Londrina essa passagem é marcante entre o final dos anos 1970 e início dos anos 1980.

Tais transformações permitiram a formação e expansão de empresas mais robustas, que atuaram como construtoras e incorporadoras, como a Construtora Plaenge S/A, que se tornaria a maior da Região Sul do Brasil segundo o ranking do Valor 1000 (2011). Por outro lado, a conjuntura do final dos anos 1970, marcada dentre outros, pela instabilidade política do Regime Militar e pela crise econômica deflagrada pelos choques do petróleo, 
levaram à aceleração do processo inflacionário, afetando gravemente os financiamentos imobiliários. Incorporadoras dinâmicas naquele período, como a Construtora Brasília, não resistiram às oscilações e crises e foram à falência nos anos 1980.

A partir de meados dos anos 1970 e ao longo dos anos 1980, uma nova geração de agentes produtores do urbano se firmou a partir do mercado local londrinense e expandiu suas atividades para o mercado nacional e, em pelo menos um caso, para o mercado latinoamericano. Esses novos agentes também serão responsáveis por intensificar a expansão da verticalização para os quadrantes oeste, sudoeste e sul de Londrina no período seguinte.

\section{O SEGUNDO PERÍODO DA VERTICALIZAÇÃO EM LONDRINA: ACELERAÇÃO DO PROCESSO E CONSOLIDAÇÃO DAS INCORPORADORAS E CONSTRUTORAS DE ORIGEM LOCAL.}

A evidência mais geral de que se estabeleceu um novo patamar de ação e de produção de edifícios com quatro ou mais pavimentos na cidade, é o expressivo aumento da área construída e do número de edifícios produzidos ao longo dos anos 1980 e 1990. A área construída quintuplica novamente, passando de $435 \mathrm{mil} \mathrm{m}^{2}$ nos anos 1970 para 2,1 milhões de $\mathrm{m}^{2}$ nos anos 1980. O número de edifícios foi oito vezes maior do que período precedente, nada menos que 1.412 edifícios com quatro ou mais pavimentos entre 1980 e 1999, contra 176 entre 1950 e 1979.

O gráfico 6 indica que o período apresentou variações abruptas em termos da área construída. Há uma tendência de crescimento ao longo dos anos 1980, com o pico do período ocorrendo em 1989, quando a área construída anual atingiu mais de meio milhão de $\mathrm{m}^{2}$.

Gráfico 6: Londrina, área construída de edifícios verticais: 1980-1999

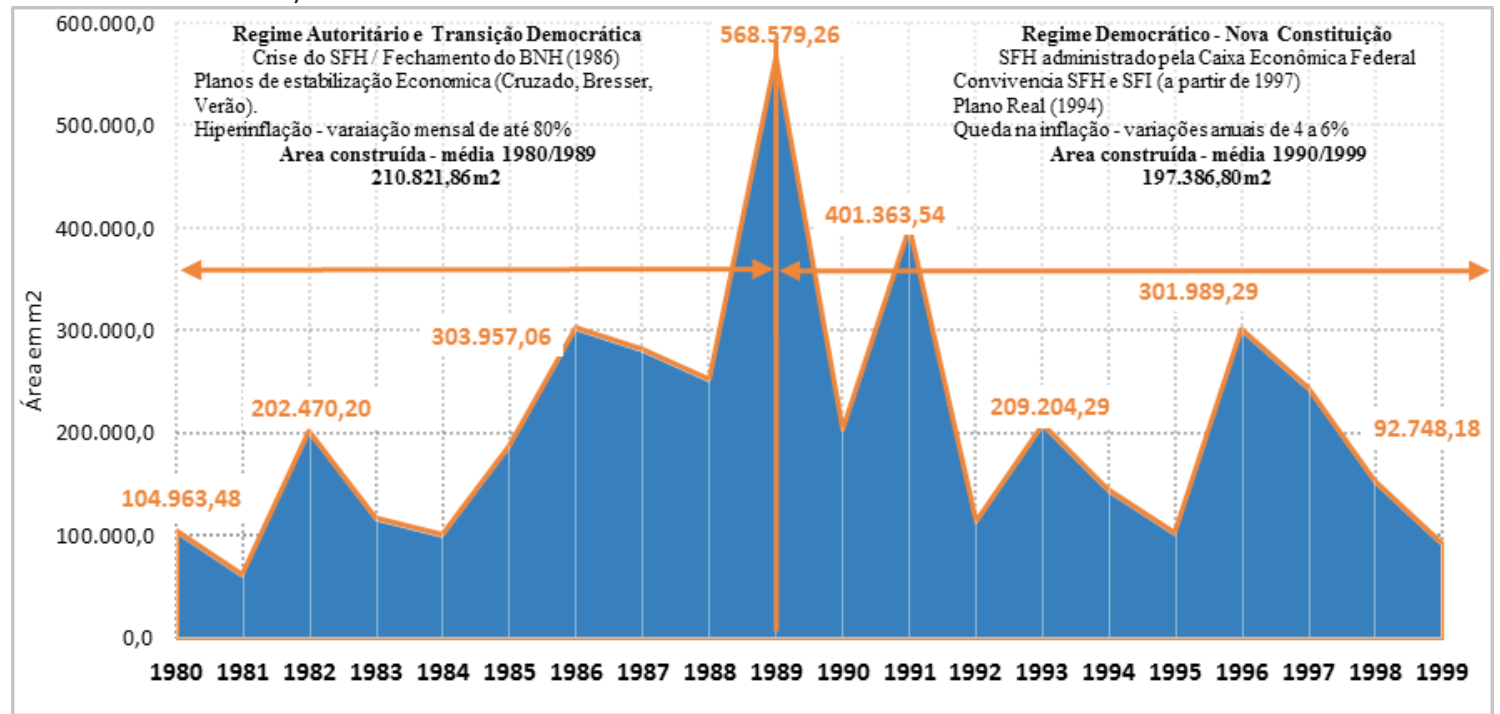

Fontes: Casaril (2008), Passos (2007) e Corpo de Bombeiros de Londrina 2013. 
Dois conjuntos de fatores evidenciaram-se como explicativos da expressiva dinâmica da verticalização londrinense nos anos 1980. O primeiro conjunto de fatores diz respeito às condições macroeconômicas do período, associadas à conjuntura política. Nos anos 1980, com a explosão do processo inflacionário, as empresas que se tornaram simultaneamente construtoras e incorporadoras, puderam se apropriar de rendimentos auferidos diretamente com a incorporação e produção de edifícios e ainda administrar ganhos suplementares com a compra antecipada de insumos. Os preços dos insumos alteravam-se mês a mês e forçavam, por meio da indexação das prestações dos mutuários via correção monetária e mudança no valor total da unidade habitacional adquirida, o aumento correspondente nas receitas das empresas. A aquisição dos insumos de forma antecipada permitia embolsar a diferença gerada pelo processo inflacionário. Por outro lado, essa compra antecipada exigia maior disponibilidade no uso do capital de giro destinado ao financiamento da obra e, portanto, uma estrutura administrativa interna ágil o suficiente para acompanhar a volatilidade dos preços. O capital dinheiro disponível nas empresas poderia ser aplicado no mercado financeiro (overnight) e, dessa forma, as empresas obtinham proteção extra contra a corrosão dos valores provocada pela inflação e, em certos casos, fontes de lucros suplementares. Assim, em relação às décadas anteriores, os anos 1980 trouxeram mudanças significativas. As antigas construtoras de capital local e de caráter familiar foram parcialmente substituídas por novas incorporadoras e construtoras com capacidade de autofinanciamento, com novos acessos a fundos públicos, como o Plano Empresário que obtinha recursos do SBPE para financiar obras geradas pelo sistema de incorporação, e com estrutura administrativa e gerencial mais complexa, exigida pela turbulência econômica do início desse segundo período.

O segundo conjunto de fatores diz respeito ao mercado imobiliário local e ao que se denomina neste texto de seletividade espacial intraurbana. Nesse caso a seletividade espacial intraurbana deve ser entendida como conjunto de condições locais que atraem, repelem e moldam processos exógenos. Uma dessas condições decorre da dinâmica populacional. Em Londrina, a população urbana saltou de 257 mil habitantes para 355 mil, um acréscimo de quase 100 mil habitantes em uma década. A dinâmica demográfica envolvendo números desse porte pressiona o mercado imobiliário na questão de habitação.

Outro aspecto inerente à formação socioespacial regional, foram mudanças econômicas trazidas pela expansão da agricultura tecnicizada, produtora de commodities exportáveis como a soja. A agroindústria aliada a essa nova base técnica e produtiva no campo, trouxe rendas elevadas que foram parcialmente capturadas por atividades urbanas prestadoras de serviços ao campo e pelo consumo produtivo (FRESCA; OLIVEIRA, 2005). 
Ampliam-se em Londrina os serviços como a educação básica e superior, saúde, especialmente serviços médicos hospitalares de média e alta complexidade e também a pesquisa realizada em instituições como a Universidade Estadual de Londrina, EmbrapaSoja e Instituto Agronômico do Paraná -IAPAR- que exigem quadros profissionais com formação superior que recebiam salários médios elevados no contexto regional. Esse segmento social irá compor parte da demanda do mercado imobiliário, especialmente na vertente habitacional e influenciar a segmentação do mercado imobiliário local (FRESCA, 2013). Juntamente com a expansão da aglomeração urbana entre Londrina e cidades adjacentemente localizadas, esses elementos são indicativos do início do processo de metropolização do espaço, do qual a verticalização é, no mínimo, um ícone.

Os grupos sociais com menores rendimentos também participaram da verticalização de forma intensiva nos anos 1980. Instituições como a COHAB-LD e o INOCOOP/PR, COHAPAR e Caixa de Aposentadorias e Pensões da Prefeitura de Londrina (CAAPSML) viabilizaram a construção de 133 edifícios de mais de quatro pavimentos, o equivalente a 18\% dos edifícios, cujo total construído foi de 746 .

Nos anos 1990 a tendência de construção de edifícios foi declinante até 1995, conforme gráfico 6. Fatores como a crise da política habitacional e a nova administração do SFH pela Caixa Econômica Federal, afetaram a construção civil e particularmente os financiamentos habitacionais necessários à verticalização. Some-se a isso a crise política do Governo Collor, que afetou a economia como um todo por meio do confisco da poupança, abertura e desregulamentação dos mercados, aumento da taxa de juros e recessão. A partir de 1994, com o plano real, a realidade econômica e dos financiamentos imobiliários ganhou novos componentes. O controle inflacionário e o neoliberalismo trouxeram o mercado para o centro das ações na política habitacional. O auge dessa orientação foi a definição de um novo marco regulatório assentado particularmente na ampliação do crédito voltado para aquisição de imóveis novos e usados e na alienação fiduciária, forma de alienação do imóvel adquirido, que estabeleceu garantias jurídicas para retomada do imóvel pelo agente financiador. Essas novas normas compõe o cerne do Sistema Financeiro Imobiliário (SFI) implantado em 1997 e que traz segurança jurídica para as incorporadoras e bancos frente aos mutuários, submetidos então aos ditames do mercado.

A nova conjuntura teve reflexos no período seguinte, favorecendo o processo de oligopolização das empresas da construção civil. Novas estratégias de concentração e centralização de capital foram adotadas pelas empresas, particularmente a abertura de capital das incorporadoras e construtoras na Bolsa de Valores de São Paulo (BOVESPA) e mudanças no controle de empresas tradicionais com a chegada de novos sócios como os Fundos Equity. 
Do ponto de vista local, os anos 1990 representaram a chegada de outras modernizações em Londrina. As condições gerais de produção dadas pelas infraestruturas de energia, telefonia, fibras ópticas e saneamento básico, aliadas à disponibilidade de força de trabalho com formação técnica e superior oriunda do conjunto de universidades públicas e particulares, além dos institutos de pesquisa, favoreceram o desenvolvimento de serviços superiores, as chamadas atividades quaternárias (GOTTMANN, 1990).

\begin{abstract}
É o que vem acontecendo com Londrina, localizada no norte do Paraná - Brasil, que desde os anos de 1990 tem ampliando atividades terciárias especializadas, como é o caso dos serviços de consultorias diversas, propaganda e marketing, gestão púbica, pesquisa e desenvolvimento, serviços de comunicação, dentre outros. Esta ampliação vincula-se de um lado, ao próprio processo de intensificação de sua participação na divisão territorial do trabalho e de outro, ao fato de ser a principal cidade de uma aglomeração urbana e sede de uma região metropolitana, que envolve uma população de cerca 800 mil habitantes, onde é complexa a divisão do trabalho (FRESCA, 2014, p.1).
\end{abstract}

Acrescente-se à dinâmica dos serviços superiores presentes em Londrina, a multiplicação das atividades comerciais urbanas com quatro shopping-centers e hipermercados de capital regional, nacional e internacional presentes até então. A presença desses grandes empreendimentos reforçou a polarização que Londrina exerce sob um vasto entorno regional.

Em consonância com o desenvolvimento capitalista da economia urbana londrinense, os agentes produtores do espaço urbano, especialmente as incorporadoras, puderam reforçar sua posição no mercado imobiliário local, tornando-se mais fortes e competitivas. Um exemplo da força das incorporadoras locais é a empresa Plaenge. Fundada em 1970, esta empresa diversificou suas atividades e constituiu um grupo empresarial que atua na construção civil com edifícios residenciais e também com montagens e construções destinadas a indústria. Esse segundo tipo de construções fica a cargo da EMISA, uma das empresas do grupo Plaenge que reúne ainda a incorporadora Plaenge e a Vanguard Home, voltadas para o segmento residencial. A partir dos anos 1980, a Plaenge passou a atuar em cidades como Cuiabá-MT e Campo Grande - MS, expandindo sua área de abrangência na escala nacional. No Paraná desenvolve empreendimentos em Curitiba e Maringá. Além de sua atuação nacional, em 1998 a empresa adquiriu uma construtora no Chile e atualmente possui empreendimentos também naquele país (FRESCA, 2013, p.71).

A Plaenge não é um caso isolado. Outro grupo empresarial da construção civil de origem local e forte presença no mercado imobiliário é o grupo A. Yoshii.

Outro destaque é o Grupo A. Yoshii composto pela A. Yoshii Engenharia, pela A. Yoshii Maringá Engenharia e pela Yticon Construção e Incorporação, sediado em Londrina. Fundada em 1965, atua nos segmentos de incorporação residencial e edificações de obras contratadas por clientes em diversas áreas. Com forte atuação no segmento industrial, corporativo e educacional, atende clientes concentrados principalmente no estado de São Paulo, Paraná e Santa 
Catarina. O Grupo passou a dedicar-se com mais intensidade nas duas últimas décadas à incorporação residencial, inclusive com a segmentação de sua atuação, onde a primeira incorpora e edifica para consumidores de maior poder aquisitivo, enquanto a Yticon, criada em 2009, destina-se a atender mercado consumidor de menor poder aquisitivo (FRESCA, 2013, p.71).

Outras empresas locais, constituídas principalmente nos anos 1980 e 1990, também merecem destaque, ainda que tenham menor expressão que as empresas Plaenge e A. Yoshii. É o caso das empresas Artenge, Galmo, Vectra e Quadra Construtora para citar apenas algumas que se destacam no quadro 2 .

Quadro 2: Principais incorporadoras e/ou construtoras atuantes em Londrina entre 1980 - 1999

\begin{tabular}{|c|c|c|}
\hline Construtoras & Área Construída (m2) & Área Construída (\%) \\
\hline Khoury Ltda & $249.731,11$ & 6,01 \\
\hline Dinardi Engenharia e Construção Civil Ltda & $230.185,65$ & 5,54 \\
\hline Mavillar Construtora e Incorporadora Ltda & $222.594,40$ & 5,36 \\
\hline Planos Construtora e Incorporadora Ltda. & $216.847,37$ & 5,22 \\
\hline Plaenge S.A. & $207.946,73$ & 5,00 \\
\hline Brasília Ltda. & $145.232,86$ & 3,50 \\
\hline Santa Cruz Engenharia Ltda & $136.964,08$ & 3,30 \\
\hline Encol S.A. & $123.072,50$ & 2,96 \\
\hline Brastec Engenharia e Construções Ltda & $114.019,94$ & 2,74 \\
\hline Quadra & $113.367,06$ & 2,73 \\
\hline Artenge/Simamura Daiwa House S.A. & $90.354,40$ & 2,17 \\
\hline A. Yoshii - Engenharia e Construção Civil Ltda & $84.076,87$ & 2,02 \\
\hline Cohab -LD & $80.246,02$ & 1,93 \\
\hline Cebel S.A. & $77.013,13$ & 1,85 \\
\hline Moro S.A. Construção Civil & $75.799,65$ & 1,82 \\
\hline Enoch Vieira dos Santos & $58.384,99$ & 1,41 \\
\hline Galmo Engenharia e Construção Ltda. & $50.355,61$ & 1,21 \\
\hline Cruciol Ltda. & $48.908,38$ & 1,18 \\
\hline Pavibras Pavimentação e Obras Ltda & $46.068,54$ & 1,11 \\
\hline Cacauenge Engenharia e Construção Ltda & $45.705,19$ & 1,10 \\
\hline Garcia Pedriali Construção Civil Ltda. & $43.659,02$ & 1,05 \\
\hline Total Parcial & $2.460 .533,50$ & 59,21 \\
\hline Total Geral* & 4.154.859,36 & 100,0 \\
\hline
\end{tabular}

*: O Total Geral representa a soma dos dados de todas as construtoras atuantes no período

Fontes: Casaril (2008), Passos (2007) e Corpo de Bombeiros de Londrina, 2013. 
No que tange a distribuição espacial da verticalização, a área central e bairros vizinhos a ela, continuaram a ser prioritários para atuação dos agentes produtores de edifícios verticais como já assinalado. Bairros próximos ao centro histórico como o Quebec a oeste e o Ipiranga ao sul, tornaram-se densamente verticalizados com predomínio de edifícios de mais de nove pavimentos, destinados a compradores com poder aquisitivo elevado no caso do jardim Quebec, e edifícios menos sofisticados destinados à classe média, no caso do bairro Ipiranga.

A presença de edifícios com quatro ou mais pavimentos, ao mesmo tempo em que torna mais densa na área central, se fez presente em praticamente todos os quadrantes da malha urbana. Ao norte da área central, a verticalização atinge bairros como o jardim Coliseu e outros do denominado Cinco Conjuntos, situados na extremidade norte da área urbana. Ao sul, a verticalização chega aos jardins Piza e Inglaterra e a leste, os bairros de Interlagos, Antares e Brasília abrigam edifícios de quatro ou mais pavimentos; no oeste a situação é semelhante. Verifica-se a presença de edifícios verticais nos jardins Jamaica, Bandeirantes e Sabará situados nas proximidades do limite oeste do perímetro urbano londrinense. De uma maneira geral, nos bairros periféricos em relação ao centro principal, predominou a construção de edifícios com quatro ou cinco pavimentos, voltados para parcela de consumidores com poder aquisitivo modesto, mas que possuíam condições de arcar com os custos das formas de financiamento disponíveis e buscavam alternativas aos conjuntos habitacionais.

Ratificando sua tendência de expansão para o sul e sudoeste, a dinâmica intraurbana da verticalização foi pouco a pouco se aproximando das áreas adjacentes ao lago Igapó, amenidade importante para estratégias espaciais do capital imobiliário. Para isso, certas ações do poder público municipal foram fundamentais. As alterações no zoneamento e a possibilidade de verticalizar áreas próximas ao Centro Cívico de Londrina, situado no quadrante sul, permitiram às novas incorporadoras locais formadas no final do primeiro período, firmar a tendência de espraiamento da verticalização nestes quadrantes. Edifícios altos, com mais de 20 andares, concentraram-se particularmente na margem esquerda do primeiro lago Igapó. 
Mapa 3: Verticalização em Londrina: segundo período - 1980 a 1999

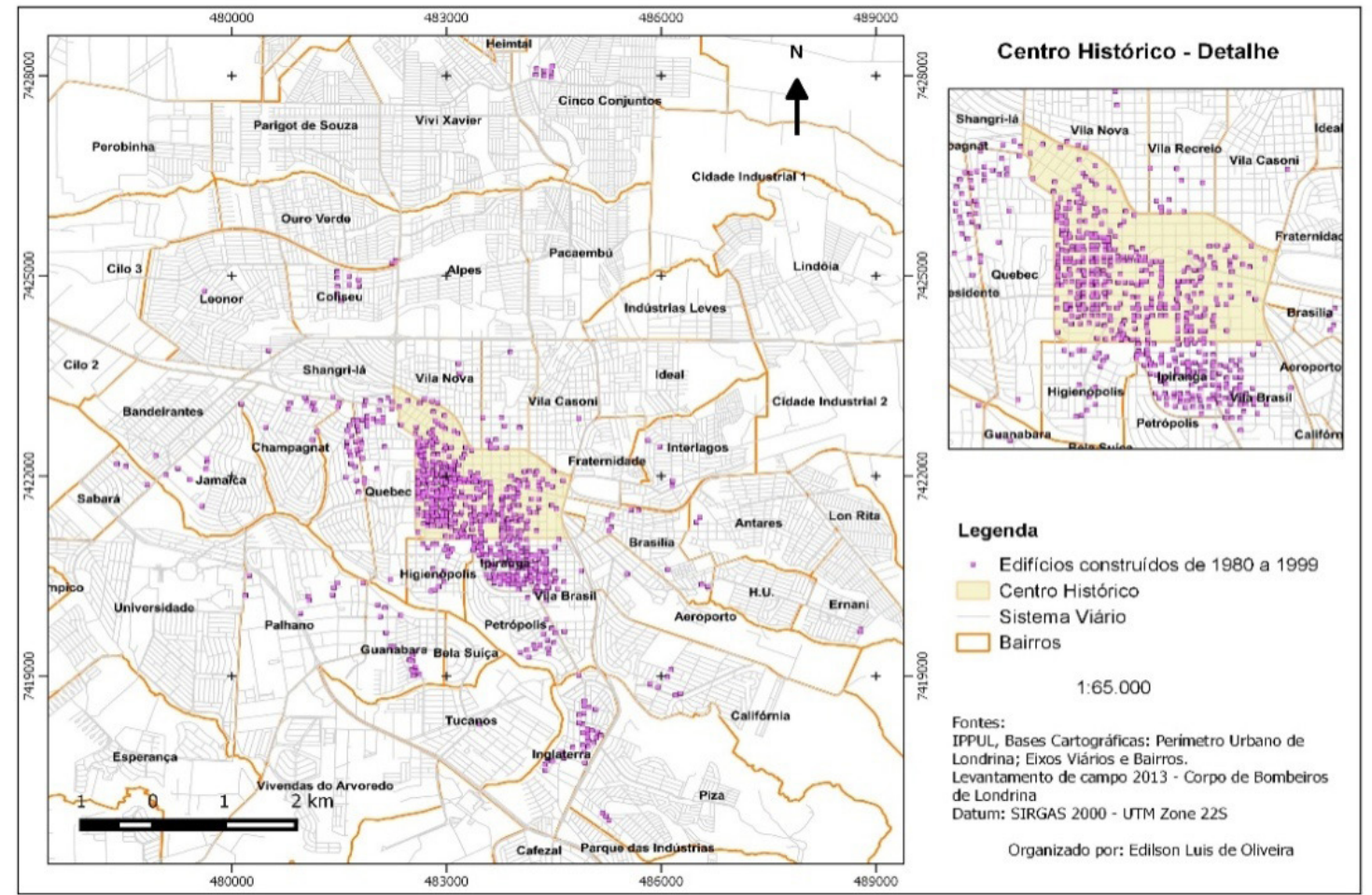

Construído no início dos anos 1960, revitalizado e melhorado sucessivamente ao longo das décadas de 1960 e 1970, o primeiro lago Igapó foi alvo de estratégias de valorização por parte das incorporadoras, porém apenas um pequeno trecho de sua margem esquerda foi aproveitado nesse sentido. A construção de um grande aterro, do segundo lago Igapó em meados dos anos 1980, do Shopping Catuaí, de uma série de condomínios fechados horizontais nos anos 1990 e a melhoria da infraestrutura viária, foram fundamentais para a constituição da segunda maior concentração de edifícios altos em Londrina: a chamada Gleba Palhano, situada na margem direita do segundo lago Igapó, ou Igapó dois como é cotidianamente denominado.

Ao longo dos anos 1990 a Gleba Palhano foi timidamente ocupada por novos edifícios.

Até o início dos anos de 1990, a porção norte da Gleba era predominantemente ocupada por chácaras e somente após a transposição da Avenida Maringá sobre o Lago Igapó, garantindo acesso a Madre Leônia, é que a Gleba passou a ser alvo da construção de edifícios. Estas obras foram executadas pelo poder público mediante pressão das construtoras e incorporadores, que requeriam a construção da mesma por garantir fluidez do trânsito e infraestrutura em suas terras previamente adquiridas (PAULA, 2006, p.75).

Como demonstra o mapa 3, alguns poucos edifícios estavam presentes na Gleba Palhano até o final dos anos 1990. Segundo Paula (2006, p.78), havia sete edifícios construídos até 1999. A dinâmica especulativa desencadeada pelas incorporadoras nessa parte da cidade se tornaria efetiva apenas no período seguinte. Isso se explica por razões como: fortes 
oscilações na política econômica nacional na primeira metade dos anos 1990; do não esgotamento de áreas disponíveis altamente valorizadas na porção sul e oeste da cidade; a distancia elevada em relação a área central na percepção de moradores; alterações no perímetro urbano municipal e infraestrutura (FRESCA, 2002). Também foi determinante a configuração de outras estratégias de valorização, como os condomínios fechados do quadrante sudoeste e do Shopping Catuaí, para que as incorporadoras intensificassem a verticalização dessa parte da cidade.

\section{O TERCEIRO PERÍODO DA VERTICALIZAÇÃO EM LONDRINA: FINANCEIRIZAÇÃO E PRESENÇA DAS INCORPORADORAS DE ORIGEM EXTERNA.}

A pujança do processo de verticalização em Londrina e seus reflexos na dimensão do mercado imobiliário da cidade, pode ser facilmente atestados pela existência de um elevado número de edifícios altos, marca indelével da paisagem urbana. Em 2013, considerando os edifícios em construção, Londrina abrigava 2111 edifícios de quatro ou mais pavimentos (NASCIMENTO, 2015, p.16 e 17). Os dados do Censo 2010 também corroboram a afirmação sobre a verticalização londrinense. Em Londrina 20\% dos domicílios particulares são apartamentos (IBGE, 2010); esse percentual é relativamente próximo do que ocorre na cidade de São Paulo, onde $28 \%$ dos domicílios são apartamentos. O quadro 3 com o número de prédios existentes com mais de 50 metros de altura é outro indicativo da posição de Londrina.

Foi exatamente essa pujança que trouxe para a cidade, novos agentes da produção espaço caracterizados pela estreita conexão com a financeirização, concentração e oligopolização das empresas do setor da construção civil (SHIMBO, 2012). Esses processos indicam a importância contínua da produção do meio construído para as dinâmicas ativas de acumulação de capital na fase monopolista do modo de produção capitalista e de ampliação da globalização financeira. 
Quadro 3: Cidades brasileiras com maior número de edifícios existentes acima de 50 metros, 2015

\begin{tabular}{|c|c|c|}
\hline Cidade & Pop. Total 2014 & Edificios Existentes \\
\hline São Paulo & 11.895 .893 & 6598 \\
\hline Rio de Janeiro & 6.453 .682 & 2833 \\
\hline Campinas & 1.154 .617 & 1829 \\
\hline Recife & 1.608 .488 & 1581 \\
\hline Santos & 433.565 & 1180 \\
\hline Curitiba & 1.864 .416 & 966 \\
\hline Porto Alegre & 1.472 .482 & 788 \\
\hline João Pessoa & 780.738 & 668 \\
\hline Fortaleza & 2.571 .896 & 627 \\
\hline B. Camboriú & 124.557 & 601 \\
\hline Salvador & 2.902 .927 & 594 \\
\hline Belo Horizonte & 2.491 .109 & 551 \\
\hline Londrina & 543.003 & 489 \\
\hline Brasília & 2.852.372 & 454 \\
\hline Goiânia & 1.412 .364 & 400 \\
\hline
\end{tabular}

Fonte: Emporis, 2015

A partir dos anos de 2000, o domínio das construtoras londrinenses no mercado imobiliário local, no segmento edifícios de uso residencial, foi parcialmente interrompido. Algumas empresas com sede em São Paulo e Belo Horizonte adentraram o mercado imobiliário londrinense. É o caso das empresas Rossi, MRV, Tenda/Gafisa, Thá e Bascol que, favorecidas pela expansão recente da construção civil brasileira, passaram a atuar em Londrina.

No que concerne à construção civil e ao mercado imobiliário, a conjuntura dos anos 2000 revelou uma nova fase de expansão do setor. Segundo dados da Câmara Brasileira da Indústria da Construção (CBIC), entre 2004 e 2010 o setor apresentou um crescimento de $42,4 \%$ e uma taxa média de expansão anual de 5,18\% (CBIC, 2011, p. 4). Dentre as razões desse crescimento acelerado nos últimos dez anos destacam-se: maior oferta de crédito imobiliário, redução da taxa de juros, maiores prazos de pagamento nos financiamentos imobiliários, legislação favorável ao setor imobiliário com a constituição de um novo marco regulatório embasado no SFI. 
Outro impulso vincula-se ao conjunto de políticas públicas voltadas à construção civil, tais como a desoneração fiscal que incidiu sobre insumos da construção civil, o Plano de Aceleração do Crescimento - PAC 1 e 2 - e o Programa Minha Casa Minha Vida (PMCMV) em suas duas etapas. Esse conjunto de medidas tomadas pelo governo federal teve caráter anticíclico e, ao mesmo tempo, revelava compromissos com grandes empreiteiras. Pelo lado do combate aos efeitos recessivos da crise internacional agravada em 2008, buscava-se manter a geração de empregos e o consumo em níveis elevados. Em relação ao compromisso com as empreiteiras viabilizava-se a realização das mercadorias do setor imobiliário, criando condições institucionais para resolver o principal ponto de estrangulamento do setor: o financiamento. A partir de 2009 com a efetivação do Programa Minha Casa Minha Vida, iniciou-se uma inédita oferta de crédito imobiliário concentrado principalmente, mas não apenas, na Caixa Econômica Federal.

Os desdobramentos dessa conjuntura favorável ao setor da construção civil levaram a multiplicação dos empreendimentos e dos agentes produtores do espaço em Londrina. Novas incorporadoras passaram a produzir edifícios altos na cidade.

Em relação à seletividade espacial intraurbana duas tendências se manifestaram claramente neste terceiro período. A primeira foi a continuidade do espraiamento da verticalização por diversos pontos da malha urbana de Londrina. Especialmente a MRV, uma das maiores incorporadoras e construtoras do país, adotou a estratégia de buscar localizações mais periféricas para seus empreendimentos, que tiveram como foco compradores de poder aquisitivo mais baixo quando comparados aos compradores de apartamentos na área central ou na Gleba Palhano. O público alvo da MRV em Londrina foi preferencialmente formado por compradores com rendimentos entre três e cinco salários mínimos que utilizaram subsídios do PMCMV (NASCIMENTO, 2015, p.87). A segunda tendência foi a concentração na Gleba Palhano de empreendimentos criados pelas construtoras de capital local, especialmente Plaenge, A. Yoshii, Vectra, Galmo e Artenge. Em 2013 havia 108 edifícios em construção em Londrina e desse total, 41 edifícios estavam localizados na Gleba Palhano (NASCIMENTO, 2015, p.99). Outro aspecto a ressaltar é o predomínio de edifícios com mais de 20 pavimentos na Gleba Palhano, incluindo os dois edifícios mais altos da cidade que possuem mais de 30 pavimentos.

A partir de meados dos anos 1980 e ao longo dos anos 1990, as incorporadoras citadas adquiriram grandes lotes oriundos de chácaras existentes anteriormente na Gleba Palhano. Com as melhorias já citadas no entorno da Palhano essas empresas puderam se beneficiar da intensa valorização gerada pelo solo criado no contexto da verticalização. As táticas específicas de cada empresa variaram conforme o controle obtido sobre parcelas de terra

a na área a ser verticalizada. 
Em entrevista com o diretor adjunto da Artenge, Sr. Sérgio Balsan Cavalaro, explicou que inicialmente a Artenge construía principalmente casas para o sistema de habitação popular - os conjuntos habitacionais - e as obras não ficavam limitadas somente na cidade de Londrina[...] A partir de 1988, a empresa começou a expandir para um novo padrão de construção, onde a construtora adquire o terreno, executa a obra, para então vender os apartamentos, num sistema de incorporação. Como a construtora já havia tido experiência com o Residencial Água Verde na Gleba Palhano (pelo sistema de contratação para execução da obra), o diretor em gestão Toshio Imai, adquiriu terrenos na região nordeste da Gleba Palhano em 1986 e em 1988 entrega as primeiras unidades do Residencial do Lago I, já pelo sistema de incorporação. "A aquisição e construção de edifícios nesta região foi uma tentativa bem sucedida por Toshio. Ele viu que a região tinha um potencial, pois a cidade não tinha mais onde construir prédios deste porte" diz Cavalaro (PAULA, 2006, p.96)

A Plaenge lidera a produção de edifícios na Gleba Palhano em termos de área construída e produziu torres altas de forma a compensar a menor dimensão das áreas integrantes de seu banco de terras (PAULA, 2006). Essa tática vem sendo explorada também por outras construtoras como a Galmo e A. Yoshii, resultando em rápida densificação da Palhano. O mapa 4 apresenta a espacialização da verticalização no terceiro período e permite verificar as tendências descritas, particularmente a concentração de edifícios na Gleba Palhano.

Mapa 4: Verticalização em Londrina: terceiro período - 2000 a 2013
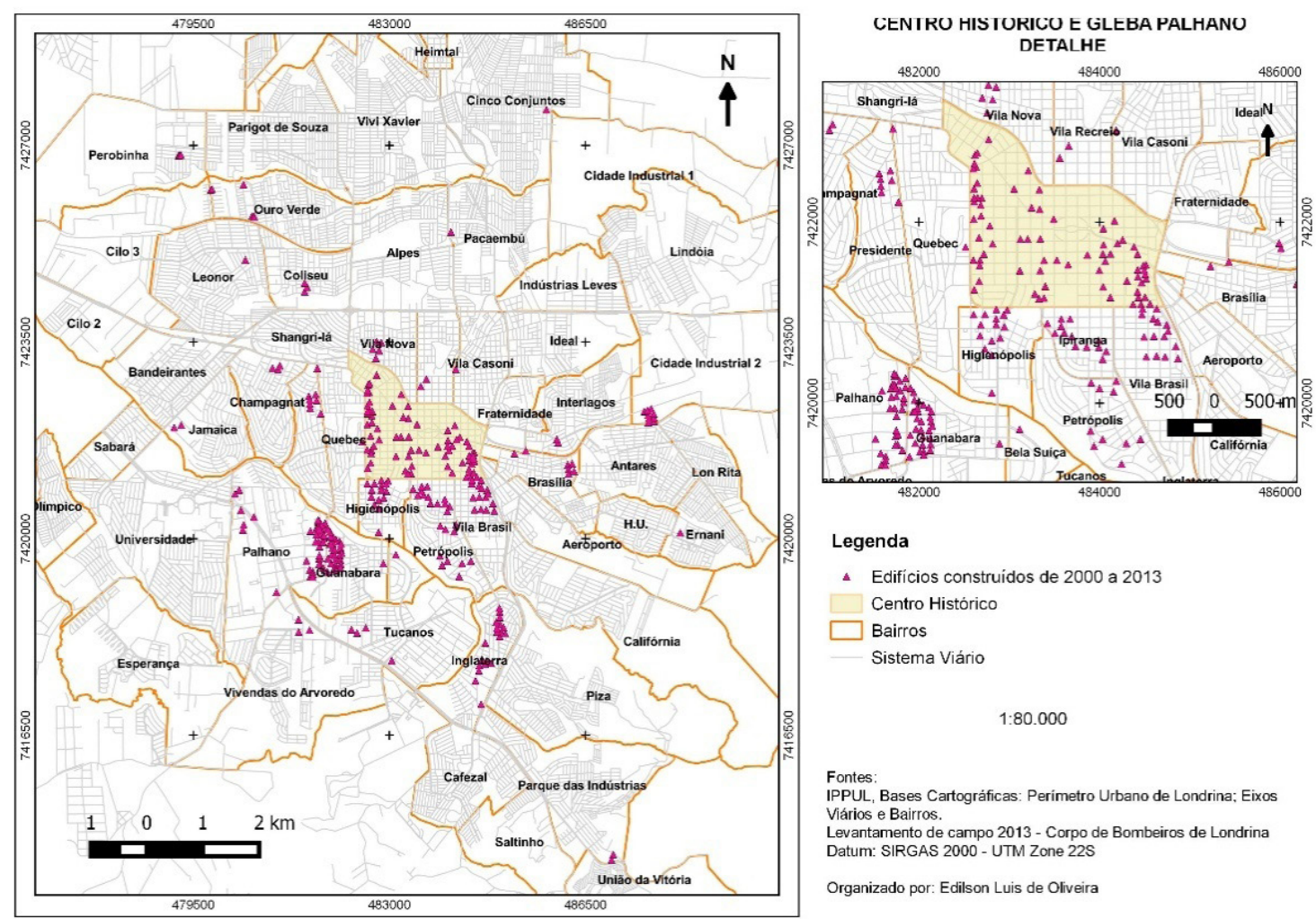

A entrada de incorporadoras de atuação nacional no mercado londrinense está em estreita sintonia com as tendências de transformação do circuito imobiliário brasileiro por forças inerentes ao processo de financeirização. Existem atualmente novas relações 
entre o urbano e os circuitos globalizados de reprodução do capital que são mediadas pelo Estado. No contexto dessas novas relações há uma forte aproximação entre o que ocorre localmente nas cidades e a reprodução do capital financeiro em escala mundial que, por meio das grandes incorporadoras, se habilita a capturar riquezas socialmente produzidas pelo processo de urbanização.

As grandes incorporadoras imobiliárias são, hoje, empresas nacionais ou internacionais de capital aberto, dispõem de estoques de terrenos (land banks) cuja soma de preços alcança patamares estratosféricos, estão preferencialmente sediadas em São Paulo e investem em projetos cada vez mais ambiciosos (SANFELICI, 2010, p. 21).

A metamorfose das incorporadoras ocorreu principalmente após o ano de 2004, em função da maior oferta de crédito imobiliário e da regulamentação de certos aspectos do novo marco regulatório estabelecido como SFI, tais como a questão do patrimônio de afetação estabelecendo a individualização das verbas, objetos e direitos de um dado empreendimento ou incorporação, separando-os do patrimônio do incorporador (BRASIL, 2004). A mesma Lei estabeleceu também a cédula e a letra de credito imobiliário como instrumentos de consolidação da aproximação entre mercado de capitais e circuito imobiliário. Ganharam importância também papéis lastreados em fluxos de recursos oriundos de alugueis e pagamentos de prestações de contratos de financiamento de imóveis, a exemplo dos Certificados de Recebíveis Imobiliários (CRI). A partir desses eventos, o crédito para financiamentos imobiliários deslancha e passa de 1,3\% do PIB em 2003 para $5 \%$ em 2011 (CBIC, 2011). O forte aumento da demanda ligada à expansão do crédito induz transformações nas construtoras e incorporadoras.

A complexa articulação entre o chamado circuito imobiliário e o mercado de capitais que constitui a essência do processo de financeirização discutido neste texto, ganha então outro aspecto que se verifica no lado da oferta. As empresas construtoras e incorporadoras passam a ampliar seus recursos financeiros por meio da captação de novos fundos em Bolsa de Valores ou por meio de sua associação com fundos financeiros de atuação global.

\footnotetext{
Os fluxos de capitais - alterados pela lógica financeira - impulsionam transformações na concorrência e na estrutura de propriedade das empresas, em suas estratégias territoriais e de mercado, no canteiro de obras e na forma imobiliária. Superam ou contornam barreiras para alargar o campo de ação do circuito imobiliário - historicamente restrito a uma parcela minoritária da população - e voltam a encontrá-las quando os limites e as contradições se manifestam (FIX, 2011, p.7).
}

Conforme o comentário de Fix (2011), a financeirização verificada no âmbito das incorporadoras e construtoras terá repercussões importantes nas estratégias territoriais dessas empresas. Esse dado reforça a perspectiva de análise desenvolvida até aqui considerando que tais estratégias se verificam de forma diferenciada, em razão da 
seletividade espacial imposta pelos diversos mercados regionais. Nesse sentido, a análise da produção do espaço metropolitano de Londrina a partir da ação das empresas construtoras e incorporadoras, pode ser considerada na perspectiva de uma teoria estruturacionista, ou seja, que preconiza como fundamento teórico “[...] o papel da ação de um lado e da estrutura de outro na produção de fenômenos e formas espaciais" (GOTTDIENER, 1993, p.199).

Dentre as novas estratégias postas em prática pelas incorporadoras, está o aproveitamento da expansão do crédito para segmentos de renda média baixa da população. Grandes incorporadoras nacionais criaram empresas e marcas especializadas, para o chamado segmento econômico (FIX, 2011, p. 136). Esse procedimento também foi adotado pelas incorporadoras londrinenses como já citado. Além de abrir novas marcas, as incorporadoras de atuação nacional abriram seu capital e passaram a negociar ações na BOVESPA, por meio da Oferta Pública de Ações (OPA). Com isso, ganharam força para expandir suas atividades para novos mercados promissores, como o da cidade de Londrina. Os novos recursos foram canalizados preferencialmente para formação de banco de terras, capital de giro e amortização de dívidas.

O setor imobiliário residencial no Brasil esteve descapitalizado desde o fim do BNH (Banco Nacional de Habitação), em meados dos anos 1980, quando perdeu sua fonte de financiamento público. Nos últimos anos, contudo, graças a intervenções ativas do governo federal e à abertura de ações, ele foi sendo recapitalizado. [...] A partir de 2006, as principais empresas construtoras e incorporadoras abriram seu capital na Bolsa de Valores, capturando bilhões de reais em poucos meses. Ao que tudo indica, gastaram grande parte na aquisição de bancos de terra. As três maiores empresas somam hoje cerca de cinco bilhões de reais em terras. Com a abertura na Bolsa e a injeção de capital, as empresas tiveram que se expandir, tanto geograficamente quanto para faixas do mercado até então inexploradas. Isso significa uma ampliação do circuito imobiliário, antes concentrado, para outras cidades e a entrada das empresas no chamado 'setor econômico' (de 6 a 12 salários mínimos de rendimento familiar) (CORREIO DA CIDADANIA, 2009).

O aporte de capital propiciado pelas OPAs permitiu que empresas como Rossi e MRV chegassem ao mercado imobiliário londrinense e enfrentassem as empresas locais, aprofundando a concorrência. No caso da MRV, empresa sediada em Belo Horizonte e uma das mais atuantes nos segmentos de renda média baixa, os incentivos de crédito oferecidos pelo PMCMV induziram a construção de diversos novos edifícios de quatro ou mais pavimentos em Londrina. Entre 2000 e 2013 a MRV foi responsável por 64 edifícios de quatro ou mais pavimentos na cidade, ultrapassando assim, as incorporadoras locais no período em questão nesse quesito (NASCIMENTO, 2015, p. 87). Vale ressaltar que as construtoras locais ainda detêm a liderança do mercado local quando se analisa a área construída e em construção neste terceiro período. Enquanto a MRV, a primeira construtora no ranking nacional 2014 da Inteligência Empresarial da Construção (ITC) no quesito 
área construída, apresenta um total de 189, 5 mil m² construídos em Londrina, a Plaenge produziu mais que o triplo, chegando a $663,4 \mathrm{mil} \mathrm{m}^{2}$. A incorporadora A. Yoshii por sua vez, produziu mais que o dobro - $480 \mathrm{mil} \mathrm{m}^{2}$ (NASCIMENTO, 2015, p.92). Lembrando ainda que, as duas gigantes locais (Plaenge e A. Yoshii) produzem prioritariamente para os segmentos de consumidores de renda média alta e rendas elevadas, o chamado segmento de luxo no contexto regional.

Outra empresa de capital nacional que iniciou sua participação no mercado londrinense foi a Rossi, sediada na cidade de São Paulo. A Rossi foi uma das empresas do setor da construção civil de maior captação de recursos na Bovespa ao longo dos anos 2000 (FIX, 2011). Seu principal investimento na cidade até o momento foi o empreendimento Palhano Business Center, localizado na Gleba Palhano, área de intensa valorização imobiliária e alvo prioritário das incorporadoras no período da financeirização. O empreendimento comercial tem área de 16,2 mil m² e cada torre tem 19 pavimentos cada. Em parceria com o grupo Thá de Curitiba, a Rossi desenvolveu também o empreendimento Victória Parque, composto por três torres de 19 pavimentos, com área total de $31,5 \mathrm{mil} \mathrm{m}^{2}$, localizado bem próximo do Shopping Catuaí (NASCIMENTO, 2015, p. 121).

Duas outras empresas estão presentes em Londrina nesse terceiro período da verticalização. Uma delas é a Bascol, empresa de capital estrangeiro incorporadora de origem portuguesa. A outra é o Grupo Thá, empresa incorporadora com sede em Curitiba e que, recentemente passou a ser controlada por capital estrangeiro (GRUPO THÁ, 2015). A participação dessas empresas em termos concretos é modesta. A Bascol possui apenas um empreendimento na cidade: o Smart City Mayrink Goes localizado na área central de Londrina, de uso misto com área construída total de $17,9 \mathrm{mil} \mathrm{m}^{2}$, composto por duas torres de 19 pavimentos cada.

O Grupo Thá tem presença um pouco mais destacada em Londrina. Como já mencionado, a empresa possui o empreendimento Victória Parque em sociedade com a Rossi. No final de 2014 a empresa anunciou três novos lançamentos: o JH Palhano e Greenwich Park situados na valorizada e disputada Gleba Palhano, e o Edifício Fly Top Life situado na porção oeste da cidade (GRUPO THÁ, 2015). Contudo, o mais importante sobre essa empresa é que ela representa emblematicamente aquela aproximação mencionada entre o mercado imobiliário local e a dinâmica global de reprodução do capital financeiro. A Thá é uma empresa centenária e conceituada de Curitiba, de base familiar que foi adquirida pelo Equity International Management, fundo de investimentos norte-americano presidido pelo investidor Sam Zell (FRESCA, 2013). O mesmo investidor controla parte do capital acionário da Gafisa (FIX, 201), incorporadora com forte atuação no mercado paulista e uma das maiores do país no ranking 2014 da ITC (2014). 
Em geral, fundos do tipo Private Equity buscam empresas consolidadas com faturamentos na casa de dezenas de milhões de dólares e programam sua permanência por um período determinado, visando obter lucros consideráveis ao longo desse tempo que é variável conforme o ramo econômico, o mercado regional e a própria relação com outros proprietários dentro da empresa (FERRARI; MINARDI, 2010). No caso de fundos Equity, a estratégia de entrada é a compra de partes de empresas de capital fechado (FERRARI; MINARDI, 2010, p.1). Visa modificar a forma de gestão da empresa para que gere lucros consideráveis durante o período de permanência do investidor, pouco importando a viabilidade do negócio em longo prazo. Empresas incorporadoras e construtoras, por exemplo, assumem estratégias competitivas mais arriscadas como a ampliação de sua base geográfica de atuação (SHIMBO, 2012, p.70) e um frenético crescimento dos lançamentos visando aumentar abruptamente seu valor líquido e sua lucratividade. Situações desse tipo podem levar a saturações de mercado que são denominadas "bolhas". No Brasil as "bolhas" tem se manifestado localmente, como no caso de Curitiba (BRODBECK, 2013). Uma das estratégias de saída dos Fundos Equity pode ser a venda de sua posição acionária em Bolsa de Valores, capturando a rentabilidade auferida pelo lote de ações, em razão da marcha forçada de crescimento do valor geral de vendas da empresa.

Diante do exposto, a forma de atuação da empresa muda em razão das pressões exercidas pelos novos participantes de sua administração. Novas estratégias que implicam crescimento rápido, até mesmo provocando saturação de mercados, são impostas às empresas. A dinâmica das transformações da estrutura urbana de muitas cidades e nesse caso, também de Londrina, resulta em parte das determinações de reprodução do capital fictício, reunido em fundos de ação global como os Fundos Equity.

Em outra direção, mas obedecendo a determinações de rápida expansão do valor dos papéis negociados em Bolsa visando o lucro de investidores globais, a intensificação e ampliação das ações de grandes incorporadoras como a MRV em Londrina, pode ser compreendida nessa perspectiva de análise. Embora permaneçam com parte de sua estrutura de gestão nos moldes tradicionais, isto é, sob controle familiar, as empresas que realizam abertura de capital em Bolsa de Valores ampliam e muito a abrangência e a intensidade de sua atuação no mercado. O resultado disso é a oligopolização do setor. Tal situação é evidente no maior mercado imobiliário do Brasil, a Região Metropolitana de São Paulo. As empresas incorporadoras financeirizadas de capital aberto atuantes naquele mercado representam $6,6 \%$ do total e respondem por $42 \%$ do mercado em termos de lançamentos e de valor gerado (SHIMBO, 2012, p.71). 
Na Região Metropolitana de Londrina as empresas financeirizadas (Thá e MRV) concentraram suas atividades em Londrina. Apenas a MRV realizou empreendimentos na vizinha cidade de Cambé ${ }^{1}$ e Arapongas. A presença dessas incorporadoras intensifica a concorrência no mercado imobiliário de Londrina dominado pelas empresas de capital fechado e de origem local. Isso resulta em maior disputa por localizações e pela capacidade de controlar o solo urbano. Tal situação traz implicações para a cidade como um todo e para seus moradores. Dentre elas destaca-se a fragmentação do espaço urbano gerada por transformações no meio construído, particularmente a intensa valorização de certas áreas, como a Gleba Palhano, e desvalorização relativa de outras, como áreas pericentrais. Essa dinâmica espacial acentua fenômenos como a segregação socioespacial, a saturação de fluxos em dadas zonas da cidade e a descentralização.

Essas são, portanto, características do terceiro período da verticalização em Londrina, período ao qual denominamos financeirização por ser o processo de maior impacto.

\section{CONSIDERAÇÕES FINAIS}

A verticalização é uma característica marcante de espaços metropolitanos e espaços metropolizados como Londrina e seu entorno regional. No espaço intraurbano de Londrina as morfologias de concentração e dispersão de edifícios verticais refletem as estratégias dos agentes construtores ao longo do tempo e as imposições geradas pelas condições locais. $\mathrm{O}$ Centro Histórico e a Gleba Palhano, áreas de concentração de edifícios verticais, representam bem a dinâmica do processo de verticalização na cidade. A primeira por sua participação nos três períodos da verticalização londrinense e a última, formada recentemente por representar a força das incorporadoras/construtoras de capital local frente à concorrência externa. Ao mesmo tempo, enquanto áreas com forte concentração de edifícios estão consolidadas, a tendência de dispersão ou espraiamento da verticalização se fortalece. Essa síntese da dinâmica espacial da verticalização é o que se apresenta no mapa 5.

Em Londrina a verticalização, iniciada nos anos 1950, já conta com um grau de amadurecimento que se expressa pela rapidez com que captura eventos de natureza global, como a ação de incorporadoras financeirizadas.

\footnotetext{
Como exemplo tem-se o Parque Lyra, empreendimento com seis edifícios e 192 apartamentos de dois dormitórios, situado no Jardim Morumbi, zona sul de Cambé/PR. Há também outro empreendimento denominado Spazio Lafayette no Jardim Montecatini na mesma cidade.
} 
A captura desse evento global, a presença de incorporadoras financeirizadas conduzidas parcial ou totalmente por Fundos Equity ou redefinidas pela exigência de valorização gerada pela abertura de capital na Bolsa de Valores, é parte da seletividade espacial que se constitui no encontro entre esses eventos globais e as características locais.

Mapa 5: Verticalização em Londrina: 1950 a 2013
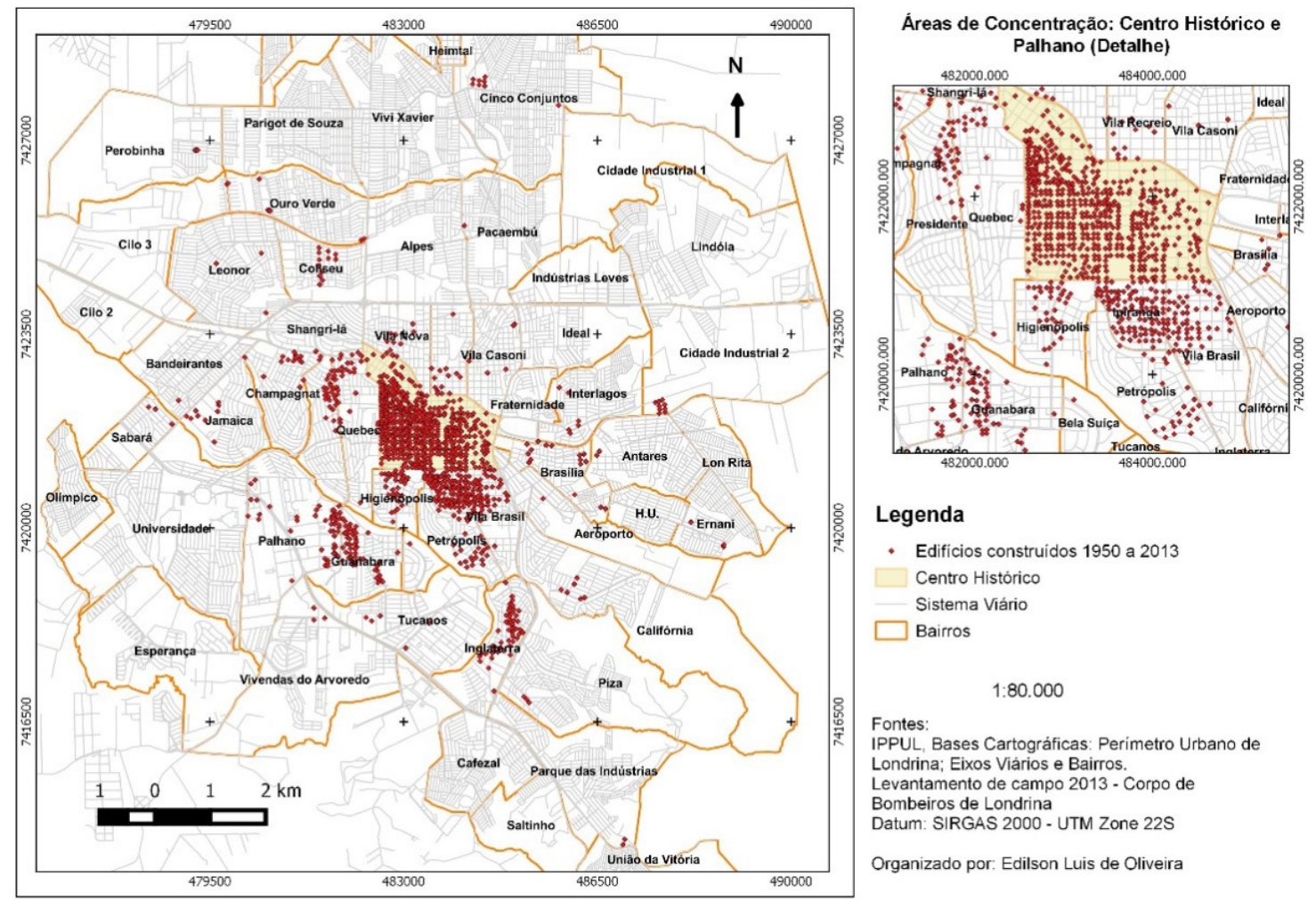

\section{Legenda}

- Edificios construidos 1950 a 2013

Centro Historico

Sistema Viário

$\square$ Bairros

$1: 80.000$
Fontes: $\quad$ IPPUL, Bases Cartográficas: Perimetro Urbano de

Londrina; Eixos Viários e Bairros.

Levantamento de campo 2013 - Corpo de

Bombeiros de Londrina

Datum: SIRGAS 2000 - UTM Zone 22S

Organizado por: Edilson Luis de Oliveira

Também é parte da seletividade espacial a resistência de incorporadoras locais que controlam ativos importantes para a produção do espaço: acesso a informações, ligações políticas, controle e apropriação de áreas potencialmente urbanizáveis, influência sobre as políticas de expansão da cidade, entre outros.

Ao longo dos sessenta anos do processo de verticalização da cidade o controle das empresas locais se consolidou a ponto de que empresas locais, particularmente as que se formaram nos anos 1970 e 1980, passassem a ter atuação nacional e até internacional. Assentadas em seu domínio do mercado londrinense foram capazes, até o momento, de manter intacta a propriedade do capital e a gestão de suas decisões corporativas que refletem estratégias competitivas mais cautelosas. Atentas à fragmentação do espaço urbano que se traduz na segmentação do mercado consumidor, por meio de faixas de renda e de produtos imobiliários destinados a essas faixas, as empresas de capital local criaram novas marcas voltadas, sobretudo, à captura dos fundos públicos via PMCMV, enquanto suas matrizes 
mantém suas marcas ligadas à oferta de apartamentos para consumidores mais abastados. As novas empresas financeirizadas com origem exógena, até o momento, não conseguiram se estabelecer nessa fatia mais lucrativa do mercado imobiliário londrinense.

Assim, a análise e periodização da verticalização em Londrina revelam o quanto a geografia dos eventos globais requer em contrapartida um conhecimento igualmente apurado e minucioso das condições locais.

\section{REFERÊNCIAS}

1. ANITELLI, Felipe; TRAMONTANO, Marcelo. Edifícios de apartamentos, São Paulo, anos 1950: mercado imobiliário e (um pouco de) arquitetura. Revista do Programa de Pós-Graduação em Arquitetura e Urbanismo da FAUUSP, São Paulo, v. 19, n. 31, p. 66-81, 2012.

2. ALVES, Claudia Lima E. Dinâmica espacial de produção e reprodução do capital e da força de trabalho em Londrina: conjuntos habitacionais. 1991. 188 f. Dissertação (Mestrado em Geografia Humana) - Departamento de Geografia, Universidade de São Paulo, São Paulo.

3. BRASIL. Decreto 5481 de 25 de junho de 1928. Dispõe sobre a alienação parcial dos edifícios de mais de cinco andares e dá outras providências. Disponível em: < http://www.planalto.gov. br/ccivil_03/decreto/1910-1929/D5481.htm >. Acesso em 08/06/2015.

4. __ Decreto-Lei 4598 de 20 de agosto de 1942. Dispõe sobre aluguéis de residências e dá outras providencias. Disponível em: < http://www2.camara.leg.br/legin/fed/declei/1940-1949/ decreto-lei-4598-20-agosto-1942-414411-publicacaooriginal-1-pe.html>. Acesso em 08/06/2015.

5. L_ Lei 4591 de 16 de dezembro de 1964. Dispõe sobre o condomínio em edificações e as incorporações imobiliárias. Disponível em: < http://www.planalto.gov.br/CCIVIL_03/leis/ L4591.htm >. Acesso em 06/06/2015.

6. Le L L L 10931 de 02 de agosto de 2004. Dispõe sobre o patrimônio de afetação de incorporações imobiliárias, Letra de Crédito Imobiliário, Cédula de Crédito Imobiliário, Cédula de Crédito Bancário, altera o Decreto-Lei nํㅜ 911, de $1^{\circ}$ de outubro de 1969, as Leis $\mathrm{n}^{\circ} 4.591$, de 16 de dezembro de 1964, nㅡ 4.728, de 14 de julho de 1965, e no 10.406, de 10 de janeiro de 2002, e dá outras providências. Disponível em: < http://www.planalto.gov.br/ccivil_03 /_ ato2004-2006/2004/lei/110.931.htm> . Acesso em 06/06/2015.

7. BRODBECK, Pedro. Gigantes do setor saem de fininho. In: Gazeta do Povo, Curitiba, 19 nov. 2013, Imóveis. Disponível em: < http://www.gazetadopovo.com.br/economia/gigantes-dosetor-saem-de-fininho-37qb6yqohh9ejlepymms05t8u >. Acesso em 07/06/2015.

8. CASARIL, Carlos C. Meio século de verticalização urbana em Londrina-PR e sua distribuição espacial: 1950-2000. 2008. Dissertação (Mestrado em Geografia) - Universidade Estadual de Londrina, Londrina.

9. Construção: cenário e perspectivas: Banco de Dados da Câmara Brasileira da Indústria da Construção. Brasília: CBIC, 2011. 
10. CORPO DE BOMBEIROS DE LONDRINA. 3 Grupamento de Bombeiros. Relatório de aprovação de projetos: 1997-2013. Londrina, 2013.

11. CORREIO da CIDADANIA. Como o pacote habitacional colabora para que as construtoras saiam da crise? Disponível em: $<$ http://www.correiocidadania.com.br/index2. php?option=com_content\&do_pdf=1\&id=3573>. Acesso em 25/05/2015.

12. DE AZEVEDO, Sergio. Vinte e dois anos de política de habitação popular (1964-86): criação, trajetória e extinção do BNH. Revista de Administração Pública, São Paulo, v. 22, n. 4, p. 107-119, 1988.

13. DIAS, L. C. Reorganização das redes bancárias no Brasil: concentração e expansão geográfica. In: MARTINS, César Augusto Ávila; MARTINS, S. Fraga; SILVA, Susana M. V. da (Org.). Quintas urbanas: cidades e possibilidades. 1ed. Rio Grande: Editora da FURG, 2011, v. 1, p. 25-42.

14. EMPORIS. Building directory. Disponível em $<$ http://www.emporis.com/corporate $>$ Acesso em 30/11/2015.

15. FERRARI, Guilherme Lopes; MINARDI, Andrea Maria Accioly Fonseca. O desempenho de ofertas públicas inicias de empresas brasileiras financiadas por fundos de private equity. Insper Instituto de Ensino e Pesquisa, São Paulo, 2010. Disponivel em: < http://www.insper.edu.br/working-papers/working-papers-2010/o-desempenho-de-ofertaspublicas-inicias-de-empresas-brasileiras-financiadas-por-fundos-de-private-equity/>. Acesso em 20/06/2015

16. FIX, Mariana A. B. Financeirização e transformações recentes no circuito imobiliário no Brasil. 2011. Tese (Doutorado em Economia) - Instituto de Economia, Unicamp, Campinas, 2011.

17. FRESCA, Tânia Maria. A rede urbana norte-paranaense e cidades especializadas em produções industriais: Arapongas, Apucarana e Cianorte. ENCONTRO DE GEÓGRAFOS DA AMÉRICA LATINA, São Paulo, 2005. Anais... São Paulo, v. 10, p. 5.554-5.574, 2005.

18. FRESCA, Tânia Maria. Londrina-PR como espaço metropolitano: uma análise a partir dos serviços superiores. 2014. Disponível em: < http://observatoriogeograficoamericalatina.org. mx/egal14/Geografiasocioeconomica/Geografiaurbana/069.pdf > . Acesso em 20/05/2015.

19. FRESCA, T. M. Mudanças recentes na expansão físico-territorial de Londrina. Revista do Departamento de Geociências. v.11, n. ${ }^{\circ}$ 2, 2002

20. __ O espaço metropolitano de Londrina-PR: novas centralidades e mercado imobiliário. Revista de Geografia, Recife, v. 30, n. 2, p. 51-77, 2013.

21. FRESCA, Tania Maria; OLIVEIRA, E. L. A produção do espaço urbano de Londrina: 19702000. Relatório de projeto de pesquisa. Londrina: UEL, 2005.

22. GOTTDIENER, Mark. A produção social do espaço urbano. São Paulo: Edusp, 1993.

23. GOTTMANN, Jean. Urban centrality an the interweaving of quaternary activities. In: GOTTMANN, J. ; HARPER, Robert. A. Since megalopolis: the urban writings of Jean Gottmann. Baltimore and London: The Johns Hopkins University Press, 1990.

24. GRUPO THÁ, 2015. Mais de um século. Disponível em: <http://www.tha.com.br/portaltha/ grupo-tha/>. Acesso em 26/05/2015. 
25. Imóveis em Londrina. Disponível em: $<$ http://www.tha.com.br/portaltha/imoveis $>$. Acesso em 26/05/2015.

26. IBGE. Censos demográficos: 1940 a 2000. Rio de Janeiro: IBGE, 1940-2000.

27. Censo demográfico 2010. Rio de Janeiro: IBGE, 2010. Disponível em: $<$ http://www. ibge.gov.br/home/estatistica/populacao/censo2010/resultados_preliminares/preliminar_tab_ municipio_zip.shtm >. Acesso em 25 de junho de 2015.

28. ITC. Ranking ITC: as 100 maiores construtoras 2014. Disponível em: < http://rankingitc.com. br/ranking-itc-2014 >. Acesso em 21 de julho de 2015.

29. JOFFILY, José. Londres-Londrina. Rio de Janeiro: Paz e Terra, 1985.

30. LENCIONI, S. Uma nova determinação do urbano: o desenvolvimento do processo de metropolização do espaço. In: CARLOS, A. F. A.; LEMOS, A. I. (Org). Dilemas urbanos: novas abordagens sobre a cidade. São Paulo: Contexto, 2003. p. 35 - 44.

31. LINARDI, Maria Cecília N. Pioneirismo e modernidade: a urbanização de Londrina-PR. 1995. Tese (Doutorado em Geografia Humana) - Faculdade de Filosofia Letras e Ciências Humanas, Universidade de São Paulo, São Paulo.

32. NASCIMENTO, C. F. A verticalização de Londrina - PR: financeirização e mercado imobiliário entre 2000-2013. 2015. Dissertação (Mestrado em Geografia) - UEL, Londrina.

33. NANTES, Ailton da Silva. Segregação espacial: a Vila Nova de Londrina-PR. 2003. 85 f. Monografia (Bacharelado em História) - Departamento de História, Universidade Estadual de Londrina, Londrina.

34. NAKAGAWARA, Yoshiya. As funções regionais de Londrina e sua área de influência. 1972. 307 f. Tese (Doutorado Geografia Humana) - Departamento de Geografia, Universidade de São Paulo, 1972.

35. OLIVEIRA, Edilson Luis de. Divisão do trabalho e circuitos da economia urbana. Londrina: Eduel, 2011.

36. PADIS, Pedro Calil. Formação de uma economia periférica: o caso do Paraná. 2 ed. São Paulo: Hucitec, 1984.

37. PASSOS, Viviane Rodrigues de Lima. A verticalização de Londrina: 1970/2000: a ação dos promotores imobiliários. 2007. Dissertação (Mestrado em Geografia)-UEL, Londrina-PR.

38. PAULA, Rubia Graciela de. A verticalização na Gleba Palhano - Londrina/PR: uma análise da produção e consumo da habitação. 2006. Monografia (Bacharelado em Geografia) - UEL, Londrina.

39. PRANDINI, Neyde. Aspectos da geografia urbana de Londrina. In: FRESCA, T. M.; CARVALHO, M. S. Geografia e Norte do Paraná: um resgate histórico. Londrina: Edições Humanidades, 2007.v. 2.

40. RANGEL, Ignácio. Economia: milagre e anti-milagre. 2. ed. Rio de Janeiro: J. Zahar, 1986a.

41. RANGEL, Ignácio. A inflação brasileira. São Paulo: Editora Bienal, 1986b. 
42. SANFELICI, Daniel de Mello. O financeiro e o imobiliário na reestruturação das metrópoles brasileiras. Revista da ANPEGE, v. 6, n. 6, p. 17-28, 2010.

43. SANTOS, Milton. A natureza do espaço: técnica e tempo, razão e emoção. 4.ed. São Paulo: Edusp, 2004.

44. . Espaço e método. São Paulo: Nobel, 1992.

45. SHIMBO, Lucia Zanin . Habitação social de mercado: a confluência entre Estado, empresas construtoras e capital financeiro. Belo Horizonte: C/Arte, 2012.

46. SOUZA, M. A. A. de. A identidade da metrópole: a verticalização em São Paulo. São Paulo: Hucitec, 1994.

47. VALOR 1000. 1000 maiores empresas. São Paulo, v. 11, n. 11, agosto de 2011.

48. ZUCKER, Maria de Lourdes M. A industrialização de Londrina: 1980-1988. 1989. Monografia (Bacharelado em Geografia) - Departamento de Geociências, Universidade Estadual de Londrina, Londrina, 1989.a

Artigo recebido em 23 de julho de 2015.

Artigo aceito em 27 de dezembro de 2015. 